\title{
Numerical Study for Enhancement of Concentrator Photovoltaic (CPV) Cells Efficiency
}

\author{
A. A. Harb ${ }^{\text {a, }}$, Ali Radwan ${ }^{\text {b }}$, Khairy Elsayed ${ }^{\text {a,c }}$, M. Sedrak ${ }^{\mathrm{a}}$ \\ ${ }^{a}$ Department of Mechanical Power Engineering, Faculty of Engineering at El-Mattaria, Helwan \\ University, Masaken El-Helmia P.O., Cairo 11718, Egypt \\ ${ }^{\mathrm{b}}$ Dept. of Mechanical Power Engineering, Mansoura University, El-Mansoura 35516, Egypt. \\ ${ }^{\mathrm{c}}$ Mechanical Engineering Department, Arab Academy of Engineering and Technology and \\ Maritime Transport, Smart Village Branch, Egypt. \\ *Corresponding author: A. A. Harb (moneimharb@yahoo.com), Tel: 002-01023550025
}

\begin{abstract}
A study of thermal characteristics for uncooled CPV in addition to fluid flow and thermal characteristics for $\mathrm{CPV}$ integrated with a three dimensional (3D) rectangular shaped microchannel heat sink (MCHS) is numerically investigated. Steady and laminar flow of water as a coolant is used in the present study. The model is validated using different sets of data in the literature. For the cooled CPV system, the flow and thermal fields are analyzed using various channel number $(\mathrm{N}=26,52,78$ and 104), concentration ratio $(\mathrm{CR})$ ranged from 1 to 20 and mass flowrate ranged from 200 to $2000 \mathrm{~g} / \mathrm{min}$. For the uncooled CPV system, the CR ranged from 1 to 2.5 . The parameters such as solar cell temperature, temperature uniformity, electrical efficiency, electrical power, net gained power, thermal power and thermal efficiency are evaluated from the simulation. Based on the obtained results, for the uncooled system, the CR of 2.5 is the maximum value that can be used where the solar cell temperature reached to the maximum allowable temperature of $85.48{ }^{\circ} \mathrm{C}$. For the cooled system, the results show that at $\mathrm{CR}$ of 20 and mass flowrate of $200 \mathrm{~g} / \mathrm{min}$, increasing the channel number from 26 to 104 , significantly decrease the solar cell temperature from $93.2{ }^{\circ} \mathrm{C}$ to $87.3{ }^{\circ} \mathrm{C}$. As the concentration ratio increases, the cell efficiency decreases due to the increase in the cell temperature while the electrical power increases. Increasing the mass flowrate provides a remarkable enhancement in the thermal efficiency. For instance, at $\mathrm{CR}$ equals 20 and $\mathrm{N}$ of 26 , increasing the mass flow rate from $200 \mathrm{~g} / \mathrm{min}$ to $2000 \mathrm{~g} / \mathrm{min}$ increases the thermal efficiency from $43 \%$ to $71.7 \%$.
\end{abstract}

Keywords: Concentrator photovoltaic; Microchannels; Heat sink; Concentration ratio. 


\section{Introduction}

Due to the depletion of fossil fuel, the solar energy demand is increased. One of the most promising techniques used to direct conversion of solar radiation into electrical energy output is the solar photovoltaic cells (PV). However, the large area of the semi-conductors used make it very expensive. So, an alternative technique was proposed to reduce the lager area of semi-conductors and consequently its cost. This system is called concentrator photovoltaic system. In this system, the solar radiation is concentrated by mirrors or lenses and falls on the solar cells. The solar cell receives more radiation compared to the traditional PV system, leading to increase its operating temperature. The increase in the temperature significantly affects its performance by reducing the solar energy to electrical energy conversion and reducing the life time due to the degradation. Thus, efficient cooling is needed to increase the solar cell efficiency and life time.

Usually cooling methods are classified into two categories, passive and active. For the passive cooling, there is no need for mechanical or electrical input power because it acts through the exploitation of natural laws. In contrast, the active cooling, where external power source is required. In the photovoltaic thermal $(\mathrm{PV} / \mathrm{T})$ systems, the input power for the cooling system is a fraction of the produced cell electrical power that leads to a reduction in reduce the net gained electrical power and consequently reduces the overall system efficiency. The pumping power is usually independent of the work conditions and easily controllable.

Several cooling methods have been applied to the CPV systems. For instance, Chaudhari et al. (2014) considered the microchannel heat sinks (MCHS) with water as coolant regarded an effective technology to reduce the solar cell temperature. Tuckerman and Pease (1981) fabricated a micro-channel heat sink by chemically etching parallel channels in a $1-\mathrm{cm}^{2}$ silicon wafer. The channels had a width of 50 $\mu \mathrm{m}$ and a depth of $302 \mu \mathrm{m}$, and were separated by $50 \mu \mathrm{m}$ thick walls. Using water as cooling fluid, they demonstrated that their micro-channel heat sink was capable of dissipating a heat flux of $790 \mathrm{~W} / \mathrm{cm}^{2}$. Wang et al. (2017) used a direct-contact liquid film for the cooling of an electric heating plate. The heating plate used as a PV solar cell. The CR ranged from 300 suns to 600 suns. The effect of the water inlet temperature and the flow rate at different values on the temperature uniformity and average cell temperature were studied. The results indicated that the difference between the maximum and the minimum temperature was around $10{ }^{\circ} \mathrm{C}$. This temperature distribution is caused by the wavy flow of the film liquid. They also concluded that increasing the flowrate has a slight effect on the temperature uniformity. And increasing the concentration ratio from 300 suns to 600 suns leads 
to an increase in the heat plate average temperature by $10^{\circ} \mathrm{C}$ and $5^{\circ} \mathrm{C}$ when the water inlet temperature was at $30^{\circ} \mathrm{C}$ and $75^{\circ} \mathrm{C}$ respectively.

Among the PV/T system cooling techniques is impinging jets was studied by Royne et al. (2004), water immersion was investigated by Sun et al. (2014), heat pipes was conducted by Anderson et al. (2008) and Geng et al. (2012).

Recently, the MCHS with nontraditional coolants like nanofluids were also offered a significant cooling performances for CPV system. The study of flow and thermal fields for a steady-laminar flow was performed by Adham et al. (2016). The working fluid was a $\mathrm{SiC}-\mathrm{H}_{2} \mathrm{O}$ and $\mathrm{TiO}_{2}-\mathrm{H}_{2} \mathrm{O}$ nanofluids at different volume fractions passing through a rectangular channel. Optimization technique is used to minimize two objective functions, the first objective function is the total thermal resistance and the second is the pumping power. They reported that there are a decrease in the thermal resistance as the nanofluid concentration increases. Increasing the nanofluids concentration leads to an increase in the flow resistance. Eventually, the pumping power is increased. Moreover, they indicated that increasing the aspect ratio (height/width) leads to a reduction in the thermal resistance and an increase in the pumping power. Further, Radwan et al. (2016) studied the effect of the CR and the flowrate on the performance of the low CPV/T. It was found that the electrical efficiency reached approximately $18.5 \%$ at Reynolds number (Re) of 100 and 4\% SiC-water nanofluids, and the thermal efficiency achieves the maximum value of $62.5 \%$ at CR of 40 , while the loss in the power due to microchannel friction is around $0.4 \%$ of the electrical power output. Also it is indicated that the microchannel has a significant effect on the solar cell temperature by decreasing its temperature from $62.1^{\circ} \mathrm{C}$ to $33.45^{\circ} \mathrm{C}$ at the maximum value of the solar radiation. $\mathrm{Xu}$ et al. (2016) used the sequential quadratic programming technique to determine the optimum design of the MCHS. In their study, the thermal resistance was the objective function while the pressure drop was taken as one of the constraints. The results showed that the optimized microchannel number, layer, height, and width are $40,2,2.2 \mathrm{~mm}$, and $0.2 \mathrm{~mm}$, respectively, and its corresponding total thermal resistance for the whole MCHS was $0.0424 \mathrm{~K} / \mathrm{W}$. Also, it is found that after the optimizing process, the maximum temperature of the microchannel heat sink was reduced by $31.2{ }^{\circ} \mathrm{C}$ with respect to the initial design. Also, it is revealed that the shorter channel leads to a smaller thermal resistance. The good heat transfer property of heat sink is at the expense of higher pumping power. Also, it is found that as the aspect ratio and the number of channel increases the maximum temperature of the microchannel decreases asymptotically. Du et al. (2012) experimentally compared CPV module with water cooling and fixed PV without cooling. The study was performed by evaluating the performance of two systems for different performance parameters such as the efficiency, the power output and the temperature. The results showed that the maximum temperature 
difference between the CPV module and the fixed PV module was lower than $5{ }^{\circ} \mathrm{C}$ at 8.5 concentration ratio. Also, it revealed that the electrical power of the CPV system was around 4.7 to 5.2 times higher than the fixed PV system. As the solar cell temperature increases, the solar to electrical efficiency decreases. Thus, at the solar noon, the electrical efficiencies decrease for both PV systems. Since the solar cell of the CPV system receive more radiation, the electrical efficiency of the CPV was $7.81 \%$ lower than that of the fixed PV module which was $10.68 \%$.

It is noted from the above literature review that limited studies are available on the performance of both uncooled and CPV system integrated with a rectangular shaped MCHS and this has motivated the present study. Thus, the present study deals with 3D numerical simulations of steady-laminar flow and heat transfer characteristics of rectangular shaped MCHS using water as a coolant. The number of channels ranged from 26 to 104 within the range of that used by Radwan et al., (2017) for the same CPV/T system that used in the present study, mass flowrate ranged from 200 to $2000 \mathrm{~g} / \mathrm{min}$, and the $\mathrm{CR}$ ranged from 1 to 2.5 for uncooled CPV and ranged from 1 to 20 for the cooled CPV system where CR equals unity means $1000 \mathrm{~W} / \mathrm{m}^{2}$ and CR equals 20 means $20 \mathrm{~kW} / \mathrm{m}^{2}$. Results of interests such as the average cell temperature, temperature uniformity, the electrical efficiency, the electrical power, the net gained power, the thermal power and the thermal efficiency are the key parameters to illustrate the effects of $\mathrm{N}$, the mass flowrate and the $\mathrm{CR}$ on the $\mathrm{CPV}$ performance.

\section{Theoretical analysis}

In this section, the details of the physical problem, model governing equations, boundary condition, solution method, mesh independence test, and model validation are presented.

\subsection{Physical model}

Figure 1 shows the main components of the CPV integrated with the MCHS. They are a linear Fresnel lens concentrator, a solar cell, and MCHS. The dimensions of the linear Fresnel are $\mathrm{L}_{\text {lens, }}, \mathrm{W}_{\text {lens }}$, and the concentrator height $(\mathrm{H})$ are determined according to the required CR. For supporting the Fresnel lens and the reflective mirror, a steel frame is used. To achieve a natural cooling by wind above the $\mathrm{CPV} / \mathrm{T}$ modules in addition to accessibility for periodic maintenance, the ends of the concentrator are open. The incident concentrated solar radiation is partially absorbed by the solar cell. Fraction of that absorbed energy is converted to electricity, fraction is lost to the ambient, and the rest is extracted by the MCHS that mounted underneath the CPV system. As presented in Fig. 1-a, the solar radiation on the Fresnel lens is concentrated and focused onto a row of the CPV/T 
units that electrically connected in a series. While Fig.1-b shows the detailed structure of the solar cell attached to two units of MCHS. Two symmetrical MCHS are used to cool down the CPV under concentrated illumination. Dividing the flow into two heat sinks decrease the flow velocity in the microchannel which leads to decrease the total pumping power. In addition, this design could accomplish better solar cell temperature uniformity compared with the use of single MCHS. Figure 2 shows the computational domain for the CPV integrated with MCHS. In the present study a generic polycrystalline cell is used.
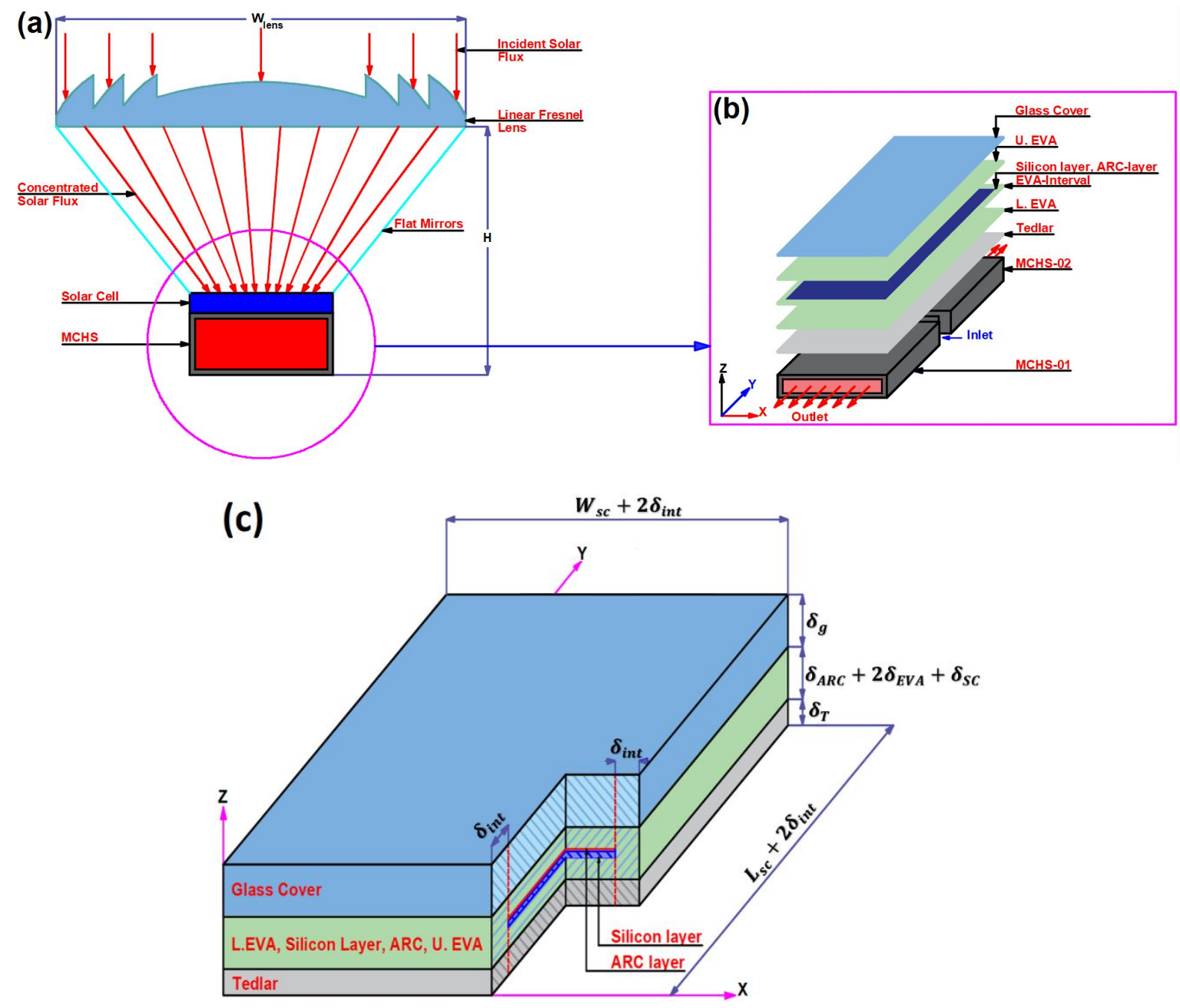

Fig.1: a) Schematic diagram for proposed linear Fresnel lens CPV/T system, b) The detailed CPV/T layers and c) structure of uncooled solar cell.

The polycrystalline silicon solar cell consists of five main layers (King et al. 2004). First, a $3 \mathrm{~mm}$ glass cover made of tempered glass with high transparency. Second, an anti-reflective coating (ARC) layer of $0.0001 \mathrm{~mm}$ thickness is used to reduce the reflection of the received radiation. Third, a silicon layer which is responsible for producing the electricity made of $0.2 \mathrm{~mm}$ thickness (Singh et al. 2016). This layer is embedded in the fourth layer of ethylene vinyl acetate (EVA) layer. The EVA layer is a transparent encapsulating material covers the silicon layer by $0.5 \mathrm{~mm}$ 
thickness above and below. The functions of this layer are maintaining the silicon layer fixed, an electrical insulation and moisture resistance. The last layer is Tedlar polyester tedlar (TPT) which is made of polyvinyl fluoride material. This layer has $0.3 \mathrm{~mm}$ thickness and it is an additional protection for the silicon layer from the moisture and provide further electrical insulation (Armstrong 2010). The typical dimensions of the investigated solar cell are $125 \mathrm{~mm}$ x $125 \mathrm{~mm}$. Each layer in the solar cell has an interval of $2.2 \mathrm{~mm}$ made from EVA (Zhou et al. 2015). This interval separate the cell from the neighboring cell. In the present study, only one cell is simulated including half of the interval part from each side. Consequently, the whole dimensions of the computational domain is $127.2 \mathrm{~mm} \mathrm{X} 127.2 \mathrm{~mm}$, consisting of a $125 \mathrm{~mm}$ silicon wafer and a $1.1 \mathrm{~mm}$ intervals from all sides.

The entire area of the solar cell is divided into two equal parts to be $127.2 \mathrm{~mm} \mathrm{X}$ $63.6 \mathrm{~mm}$. Consequently, for better temperature distribution for each solar cell unit and lower friction loss in the MCHS, two MCHS with dimensions of $127.2 \mathrm{~mm}$ by $63.6 \mathrm{~mm}$ are used to cool one CPV cell. The MCHS is fixed underneath the PV layers, and water is used as a coolant to provide better performance for CPV system by achieving high efficiency and prevent the excessive cell temperature. The entire cell area is considered in numerical calculations as the heat generation for each layer is not uniform along the cell domain as can be seen in Fig. 1-c (Zhou et al. 2015). In this work, aluminum MCHS is attached at the back side of the tedlar layer (Micheli et al. 2016). Further, water is used as a cooling liquid for its effective properties as it can generate a higher thermal performance of $\mathrm{PV} / \mathrm{T}$ systems (Tripanagnostopoulos et al. 2002).

In the current work, the channel number, $\mathrm{N}$, is changed to study its effect on the performance of the CPV system. The MCHS dimensions are channel width of 0.71 $\mathrm{mm}$, channel height of $0.823 \mathrm{~mm}$. The MCHS dimensions are within the range used by (Radwan et al. 2017, Qu and Mudawar, 2002). The coolant mass flowrate is selected to be the same for all cases for fair comparisons. Through this study, the term CR represents the net concentrated beam solar irradiance falling on the solar cell area, relative to the reference value, that usually be "one-sun" value 1000 $\mathrm{W} / \mathrm{m}^{2}$ (Xu et al. 2014). 


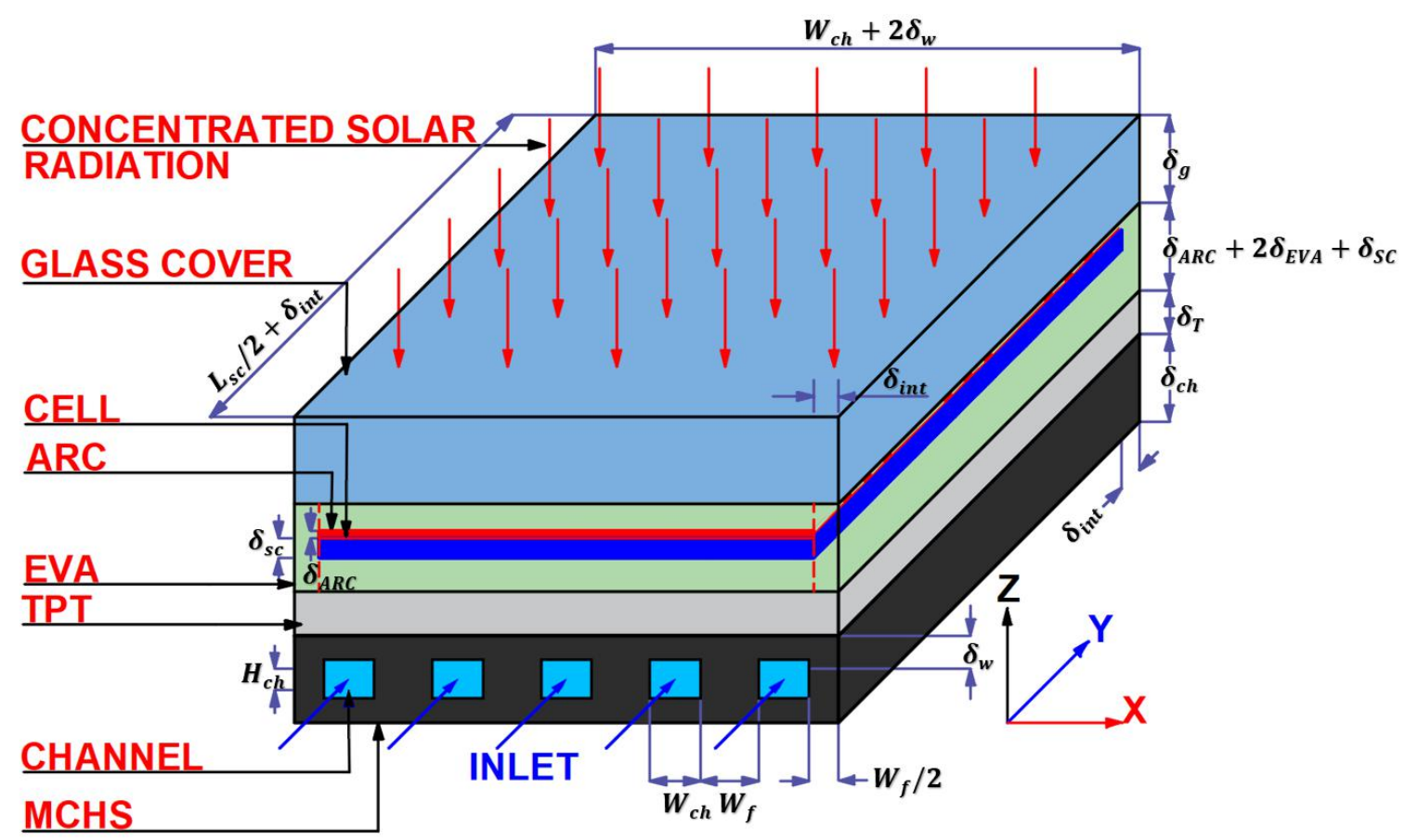

Fig.2: Schematic diagram and main dimensions of the computational domain of CPV system integrated with MCHS.

\subsection{Governing equations}

Three-dimensional fluid flow with heat transfer though the MCHS coupled with the thermal model of the CPV system is developed. Figure 2 shows a schematic structure and main dimensions of the CPV system integrated with the MCHS. The detailed dimensions of the for the four configurations are listed in Table 1

Table 1: The dimensions of different designs for the MCHS in [ $\mu \mathrm{m}]$.

\begin{tabular}{cllllllllll}
\hline Model & $\mathbf{L}_{\text {sc }}$ & $\mathbf{W}_{\text {sc }}$ & $\mathbf{W}_{\text {ch }}$ & $\mathbf{H}_{\text {ch }}$ & $\mathbf{N}$ & $\mathbf{N} / \mathbf{W}_{\text {sc }}$ & $\boldsymbol{\delta}_{\mathbf{w}}$ & $\mathbf{W}_{\text {f }}$ & $\boldsymbol{\delta}_{\text {ch }}$ & $\boldsymbol{\delta}_{\text {int }}$ \\
\hline 1 & 125000 & 125000 & 710 & 823.3 & 104 & 8.32 & 526.67 & 513.077 & 1876.67 & 1100 \\
2 & 125000 & 125000 & 710 & 823.3 & 78 & 6.24 & 526.67 & 920.769 & 1876.67 & 1100 \\
3 & 125000 & 125000 & 710 & 823.3 & 52 & 4.16 & 526.67 & 1736.154 & 1876.67 & 1100 \\
4 & 125000 & 125000 & 710 & 823.3 & 26 & 2.08 & 526.67 & 4182.308 & 1876.67 & 1100 \\
\hline
\end{tabular}

Numerical solution of the energy equation is conducted to obtain the temperature distribution in the uncooled CPV system. Moreover, the continuity, momentums, and the flow energy equations are coupled with the energy equation for the CPV layers and solved to attain the flow and heat transfer characteristics in the cooled CPV system. In order to solve model governing equations numerically. The following assumptions are considered, they are listed in Table 2 . 
Table 2: Numerical assumptions

\begin{tabular}{ll}
\hline Parameters & Assumptions \\
\hline Flow characteristics & $\begin{array}{l}\text { Three dimensional, steady, incompressible , laminar and } \\
\text { single phase } \\
\text { Body force }\end{array}$ \\
Fluid properties & $\begin{array}{l}\text { Temperature dependent (Siddiqui et al. 2013) } \\
\text { No slip boundary condition } \\
\mathrm{u}=\mathrm{v}=\mathrm{w}=0 \text { at solid liquid interfaces (Patankar et al., } \\
1980)\end{array}$ \\
Inlet velocity & Uniform (Patankar et al., 1980) \\
Solar cell materials & Isotropic and temperature independent. (Siddiqui et al., 2013) \\
Thermal contact resistances & Neglected (Siddiqui et al., 2013) \\
\hline
\end{tabular}

According to these assumptions, the conservation of mass, momentum and energy equations respectively are as follows.

\section{PV-module layers}

The heat conduction equation for each solid layer in Cartesian coordinates system can be provided as follow Radwan et al. (2017) and Siddiqui et al. (2013):

$\nabla .\left(k_{i} \nabla T_{i}\right)+q_{i}=0$ and $i=1,2, \ldots 6$

Where $k_{i}$ is the thermal conductivity of the layer $\mathrm{i}$, and $q_{i}$ is the heat generation per unit volume of the layer $i$ due to the absorption of the solar radiation. In this study, the value of $i$ varies from 1 to 6 according to the solar cell layers which are the glass cover, upper EVA, ARC, silicon layer, lower EVA and finally the TPT layer, respectively. To calculate the value of $q_{i}$, for any layer, the following equation is used Radwan et al. (2017).

$q_{i}=\frac{\left(1-\eta_{s c}\right) G \alpha_{i} \tau_{j} A_{i}}{V_{i}}$

where $\eta_{s c}$ represents the solar cell electrical efficiency, $\alpha_{i}, A_{i}$, and $V_{i}$ are the absorptivity, the area, and the volume of the layer i, respectively; and finally, $\tau_{j}$ is the net transmissivity of layers above layer $i$.

The CPV system consists of different layers as mentioned before. In each layer the absorbed solar radiation is the source of the generated heat and this absorbed solar 
radiation is a function of the layer absorptivity. For all layers (except the silicon wafer), the absorbed solar radiation is converted into heat, while for the silicon layer, the net absorbed solar irradiance is partially converted into electricity depending on the electrical efficiency while the rest is converted into heat ((1 $\left.\left.\eta_{s c}\right) * Q_{e t, a b s, s c}\right)($ Radwan et al. 2017).

To determine the heat generation per unit volume using Eq. (2), we use $\eta_{s c}$ as zero for all layers except the silicon layer (Zhou et al. 2015). The optical, thermophysical properties and dimensions for each layer are listed in Tables 3 and 4 respectively. Equation (3) is used to calculate the solar cell efficiency.

$\eta_{s c}=\eta_{\text {ref }}\left(1-\beta_{\text {ref }}\left(T_{s c}-T_{\text {ref }}\right)\right)$

where $\eta_{\text {ref }}$ and $\beta_{\text {ref }}$ represent the solar cell efficiency and temperature coefficient, respectively at a reference temperature of $T_{r e f}=25^{\circ} \mathrm{C}$. The value of $\eta_{\text {ref }}$ and $\beta_{\text {ref }}$ equals 0.12 and $0.0045 \mathrm{~K}^{-1}$, respectively for polycrystalline silicon solar cell as reported by Sarhaddi et al (2010).

Table 3: Optical properties of CPV system layer (Zhou et al., 2015).

\begin{tabular}{lllll}
\hline Material & Reflectivity & Absorptivity $(\alpha)$ & Transmissivity $(\tau)$ & Emissivity $(\varepsilon)$ \\
\hline Glass cover & 0.04 & 0.04 & 0.92 & 0.85 \\
EVA layer & 0.02 & 0.08 & 0.90 & --- \\
Silicon & 0.08 & 0.90 & 0.02 & --- \\
Layer & & 0.128 & 0.012 & 0.9 \\
Back sheet & 0.86 & --- & --- & 0.9 \\
Aluminum & --- & &
\end{tabular}

Table 4: Thermophysical properties and thicknesses of CPV/T layers (Radwan et al., 2017).

\begin{tabular}{lllll}
\hline Layer & $\begin{array}{l}\text { Density } \\
\left(\mathrm{kg} / \mathrm{m}^{3}\right)\end{array}$ & $\begin{array}{l}\text { Specific heat } \\
(\mathrm{J} / \mathrm{kg} \mathrm{K})\end{array}$ & $\begin{array}{l}\text { Thermal } \\
\text { conductivity }(\mathrm{W} / \mathrm{m} . \mathrm{K})\end{array}$ & $\begin{array}{l}\text { Thickness } \\
(\mathrm{mm})\end{array}$ \\
\hline Glass Cover & 3000 & 500 & 2 & 3 \\
ARC & 2400 & 691 & 32 & 0.0001 \\
$\begin{array}{l}\text { Encapsulation } \\
\text { (EVA) }\end{array}$ & 960 & 2090 & 0.311 & 0.5 \\
$\begin{array}{l}\text { Silicon } \\
\text { Tedlar }\end{array}$ & 2330 & 677 & 130 & 0.2 \\
$\begin{array}{l}\text { Microchannel } \\
\text { (Aluminum) }\end{array}$ & 1200 & 1250 & 0.15 & 0.3 \\
\hline
\end{tabular}




\section{Microchannel Heat Sink}

For a microchannel substrate, the heat conduction equation in the vector form without heat generation could be written as follow (Siddiqui, 2013):

$$
\nabla .\left(k_{c h} \nabla k_{c h}\right)=0
$$

For microchannel heat sink, the fluid flow and energy equations of laminar, incompressible, and steady flow can be written in vector form as follows:

Mass conservation equation:

$$
\nabla \cdot(\rho \overrightarrow{\mathrm{V}})=0
$$

Momentum equations:

$$
\overrightarrow{\mathrm{V}} \cdot \nabla(\rho \overrightarrow{\mathrm{V}})=-\nabla \mathrm{P}+\nabla \cdot(\mu \nabla \overrightarrow{\mathrm{V}})
$$

Energy equation:

$$
\overrightarrow{\mathrm{V}} . \nabla\left(\rho C_{f} T_{f}\right)=-\nabla \cdot\left(k_{f} \nabla T_{f}\right)
$$

where the subscript $f$ refers to fluid;

$\overrightarrow{\mathrm{V}}, P, \mu, \rho, C_{f}, k_{f}$, and $T_{f}$ are the velocity vector, pressure, fluid viscosity, density, specific heat, thermal conductivity, and temperature, respectively. The variation of water's thermophysical properties with temperature is considered using the higher ordered polynomial equations presented in Jayakumar (2007) due to the substantial changes that occur inside the microchannel, especially at higher $\mathrm{CR}$ values.

\section{PV Characterizations}

One of the important parameters to evaluate the performance is the electrical power, $P_{e l}$, produced by the CPV system. $P_{e l}$ Equation (8) as used by Radwan et al., (2017) is,

$P_{e l}=\eta_{s c} \tau_{g} \beta_{s c} G(t) w_{s c} l_{s c}$

where $\eta_{s c}, \tau_{g}, \beta_{s c}, G(t), w_{s c}, l_{s c}$ are the solar cell efficiency, the glass transmissivity, the net concentrated solar radiation incident on the solar cell surface regardless of the concentrator's optical losses, and the width and length of the solar cell, respectively. The thermal energy gained is determined as follow:-

$P_{\text {th }}=\dot{m}_{f} C_{f, \text { in }}\left(T_{f, \text { out }}-T_{f, \text { in }}\right)$ 
Where, $P_{t h}$ is the rate of thermal energy and $C_{f, \text { in }}$ is the specific heat of the water at the channel inlet. While $T_{f, \text { out }}$ and $T_{f, \text { in }}$ are the average fluid temperature at the outlet and inlet of the microchannel heat sink, respectively. To estimate the other performance parameters such as friction power $\left(P_{\text {fric }}\right)$, the net gained power $\left(P_{n e t}\right)$ and thermal efficiency $\left(\eta_{t h}\right)$, the equations are presented in Appendix A.

\subsection{Boundary Conditions}

For the cooled CPV system, the thermal boundary condition for the upper wall of the glass layer is a combination of convection and radiation heat loss. Further, adiabatic boundary condition is adopted for the side walls of the computational domain due to smaller thickness of the solar cell sides. For highest thermal energy gained from the cooled CPV system, the lower wall of the computational domain is also assumed to be adiabatic. At the inlet, uniform velocity is applied according to the desired coolant mass flowrate Eq. (10). While, at the channel outlet, the outlet flow boundary condition is identified with a zero-outlet gage pressure. At the solidfluid interface, the no slip and no temperature jump boundary conditions is adopted. This because, the Knudsen number $\left(\mathrm{K}_{\mathrm{n}}\right)$ falls in the no-slip regime (i.e. $\mathrm{K}_{\mathrm{n}}$ less than 0.001) (Dehghan et al., 2014). Where $K_{n}$ is the ratio of the molecular mean free path length to the flow characteristic dimension which defined as follows:

$\dot{m}=N \rho_{\text {in }} V_{\text {in }}\left(H_{c h} \times W_{c h}\right)$

$K_{n}=\frac{\lambda}{D_{h}}, D_{h}=\frac{2\left(H_{c h} \times W_{c h}\right)}{\left(H_{c h}+W_{c h}\right)}$

For the uncooled CPV system, the top surface of the solar cell is exposed to the ambient, consequently this surface is subjected to combined convective and radiation heat loss, while for the back surface of the TPT, the same conditions are applied but with heat transfer coefficient smaller than the value at the top surface as indicated by Zhou et al. (2015). There are several empirical correlations were used to determine the back-side heat transfer coefficient and it was found to be approximately equals half the value of the heat transfer coefficient of the top surface as reported by Loveday et al. (1996) and Zhou et al. (2015). Finally, all sides of the solar cell are assumed to be adiabatic. To save the computational time, half of the solar cell is modeled, and the results are reflected onto the second half. In more details, the boundary conditions for the half solar cell integrated with its MCHS are presented as follows:

\section{The PV layers:}

For upper side of the glass cover (Siddiqui, 2013): 


$$
\begin{aligned}
& 0 \leq x \leq\left(W_{s c}+2 \delta_{i n t}\right),\left(L_{s c} / 2+\delta_{i n t}\right) \leq y \leq\left(L_{s c}+2 \delta_{i n t}\right), \text { and } \\
& z=\left(\delta_{c h}+\delta_{T}+2 \delta_{E V A}+\delta_{A R C}+\delta_{s c}+\delta_{g}\right) \\
& k_{g} \frac{\partial T}{\partial z}=h_{\text {rad.g-s }}\left(T_{g}-T_{s}\right)+h_{\text {conv.g-a }-a}\left(T_{g}-T_{a}\right)
\end{aligned}
$$

Where $h_{\text {rad.g-s }}$ is the equivalent radiative heat transfer coefficient and determined using Eq. (14) and $h_{\text {conv.g-a }}$ represents the convective heat transfer coefficient and estimated using Eq. (15) and $T_{s}$ is the sky temperature and calculated from Eq. (16). For the glass cover, EVA, ARC, silicon, and tedlar sides, at the two planes parallel to the $\mathrm{yz}$ plane and located at $\mathrm{x}=0, \mathrm{x}=2 \delta_{i n t}+W_{s c}$ and $\mathrm{y}=\left(L_{s c} / 2+\delta_{\text {int }}\right)$ to $\mathrm{y}=L_{s c}+2 \delta_{\text {int }}$ an adiabatic boundary condition is applied due to the symmetry as follows.

$k_{i} \frac{\partial T}{\partial x}=0$

$h_{r a d, g-s}=\frac{\sigma \varepsilon\left(T_{g}^{4}-T_{s}^{4}\right)}{\left(T_{g}+T_{s}\right)}$

$h_{\text {con, } g-a}=5.82+4.07 V_{w}$

$T_{s}=0.0522 T_{a}^{1.5}$

where $k_{i}$ is the material thermal conductivity of layer $i$ and its value varies from material to another as given in Table 4. Similarly, at planes parallel to xz plane and located at $\mathrm{y}=\left(L_{s c} / 2+\delta_{\text {int }}\right)$ and $\mathrm{y}=L_{s c}+2 \delta_{\text {int }}$ except the coolant inlet and outlet regions, an adiabatic boundary condition is assumed due to the symmetry.

$k_{i} \frac{\partial T}{\partial y}=0$

For the solid-solid interfaces, a thermally coupled boundary condition is applied: at the glass cover-top EVA layer interface:

$0 \leq x \leq\left(W_{s c}+2 \delta_{i n t}\right),\left(L_{s c} / 2+\delta_{i n t}\right) \leq y \leq\left(L_{s c}+2 \delta_{i n t}\right)$, and

$z=\left(\delta_{c h}+\delta_{T}+2 \delta_{E V A}+\delta_{A R C}+\delta_{s c}\right)$

$k_{E V A} \nabla T_{E V A}=k_{g} \nabla T_{g}$

At the top EVA layer- ARC layer interface:

$0 \leq x \leq\left(W_{s c}+2 \delta_{i n t}\right),\left(L_{s c} / 2+\delta_{i n t}\right) \leq y \leq\left(L_{s c}+2 \delta_{i n t}\right)$, and

$z=\left(\delta_{c h}+\delta_{T}+\delta_{E V A}+\delta_{A R C}+\delta_{s c}\right)$ 
$k_{E V A} \nabla T_{E V A}=k_{A R C} \nabla T_{A R C}$

At ARC-silicon layer interface:

$0 \leq x \leq\left(W_{s c}+2 \delta_{\text {int }}\right),\left(L_{s c} / 2+\delta_{\text {int }}\right) \leq y \leq\left(L_{s c}+2 \delta_{\text {int }}\right)$, and

$z=\left(\delta_{c h}+\delta_{T}+\delta_{E V A}+\delta_{s c}\right)$

$k_{s c} \nabla T_{S C}=k_{A R C} \nabla T_{A R C}$

At silicon layer - bottom EVA interface:

$0 \leq x \leq\left(W_{s c}+2 \delta_{\text {int }}\right),\left(L_{s c} / 2+\delta_{\text {int }}\right) \leq y \leq\left(L_{s c}+2 \delta_{\text {int }}\right)$, and

$z=\left(\delta_{c h}+\delta_{T}+\delta_{E V A}\right)$

$k_{E V A} \nabla T_{E V A}=k_{s c} \nabla T_{s c}$

At EVA- tedlar layer interface:

$0 \leq x \leq\left(W_{s c}+2 \delta_{\text {int }}\right),\left(L_{s c} / 2+\delta_{\text {int }}\right) \leq y \leq\left(L_{s c}+2 \delta_{\text {int }}\right)$, and

$z=\left(\delta_{c h}+\delta_{T}\right)$

$k_{T} \nabla T_{T}=k_{E V A} \nabla T_{E V A}$

At tedlar-aluminum channel interface:

$0 \leq x \leq\left(W_{s c}+2 \delta_{\text {int }}\right),\left(L_{s c} / 2+\delta_{\text {int }}\right) \leq y \leq\left(L_{s c}+2 \delta_{\text {int }}\right)$, and

$z=\delta_{c h}$

$k_{A L} \nabla T_{A L}=k_{T} \nabla T_{T}$

For the microchannel heat sink design fluid domain:

At the channel inlet:

$\delta_{w} \leq x \leq\left(W_{s c}+2 \delta_{\text {int }}-\delta_{w}\right), y=\left(L_{s c} / 2+\delta_{\text {int }}\right)$, and

$\delta_{w} \leq z \leq\left(\delta_{w}+H_{c h}\right)$

Then: $\vec{V}=0 \vec{i}+\left(v_{i n}\right) \vec{j}+(0) \overrightarrow{\mathrm{k}}, \mathrm{T}_{\text {in }}=30^{\circ} \mathrm{C}$

At the channel outlet:

$\delta_{w} \leq x \leq\left(W_{s c}+2 \delta_{i n t}-\delta_{w}\right), y=\left(L_{s c}+2 \delta_{i n t}\right)$, and

$\delta_{w} \leq z \leq\left(\delta_{w}+H_{c h}\right)$

$P_{\text {out }}=0($ gage $)$ and $k_{f} \frac{\partial T}{\partial z}=0$

For the microchannel heat sink material sides: 
$x=0$ and $x=\left(W_{s c}+2 \delta_{\text {int }}\right),\left(L_{s c} / 2+\delta_{\text {int }}\right) \leq y \leq\left(L_{s c}+2 \delta_{\text {int }}\right)$, and

$0 \leq z \leq\left(2 \delta_{w}+H_{c h}\right)$

$k_{s} \frac{\partial T}{\partial z}=0$

For the lower wall at:

$0 \leq x \leq\left(W_{s c}+2 \delta_{i n t}\right),\left(L_{s c} / 2+\delta_{i n t}\right) \leq y \leq\left(L_{s c}+2 \delta_{i n t}\right), \quad$ and $\quad z=0, \quad$ an adiabatic boundary condition is applied (Ahmed et al., 2016).

$-\left.k_{A L} \frac{\partial T}{\partial y}\right|_{y}=0$

For the fluid-solid interface, a no slip, and thermally coupled no slip boundary condition is applied

$k_{f} \nabla T_{f}=k_{c h} \nabla T_{c h}, T_{f}=T_{c h}$ and $u=v=w=0$

\subsection{Numerical method and mesh independence test}

In the current study the thermal model for the uncooled PV system and the thermofluid model for the cooled CPV system were simulated using the computational fluid dynamics (CFD) commercial package ANSYS FLUENT 17 code. The governing equations associated with the boundary conditions were solved numerically using the finite volume method. These equations are partial differential equations for PV layers coupled with the thermo-fluid system of partial differential equations for a MCHS. The second order upwind scheme was used to discretize the convection terms in continuity, momentum and energy equations. Before carrying out the whole simulation, grid independent study was conducted to attain independent value for the cell temperature regardless the number of grids for the whole computational domain. For uncooled study, based on the mesh independence test displayed in Fig. 3-a and Fig. 3-b, the increasing in the cell number over $1,589,500$ and 3,459,500 has no remarkable effect on the cell temperature for both uncooled and cooled CPV. Subsequently, these cell numbers are used.

\section{Model validation}

The present model was verified by comparing the current computational results with the available numerical and experimental data published by Zhou et al. (2015) and Qu and Mudawar (2002) and Radwan et al. (2017. The validation is performed through three sets of steps. At the first set, the comparison between the predicted cell temperatures for the uncooled traditional PV system with the numerical results obtained by Zhou et al. (2015) is conducted. This validation is performed at different climatic conditions where the solar radiation is ranged from 400 to 1000 
$\mathrm{W} / \mathrm{m}^{2}$. The second set, the current model predicted results of the conjugate heat transfer in the MCHS using water as a coolant is compared with numerical results obtained by Qu and Mudawar (2002). In the third set, a comparison between the predicted cell temperatures for the water cooled CPV system with the numerical results obtained by Radwan et al. (2017) is conducted.

(a)

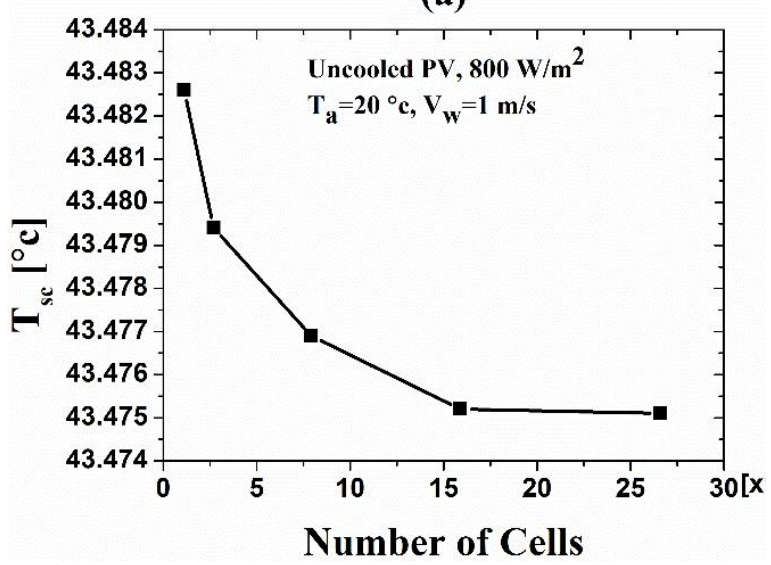

(b)

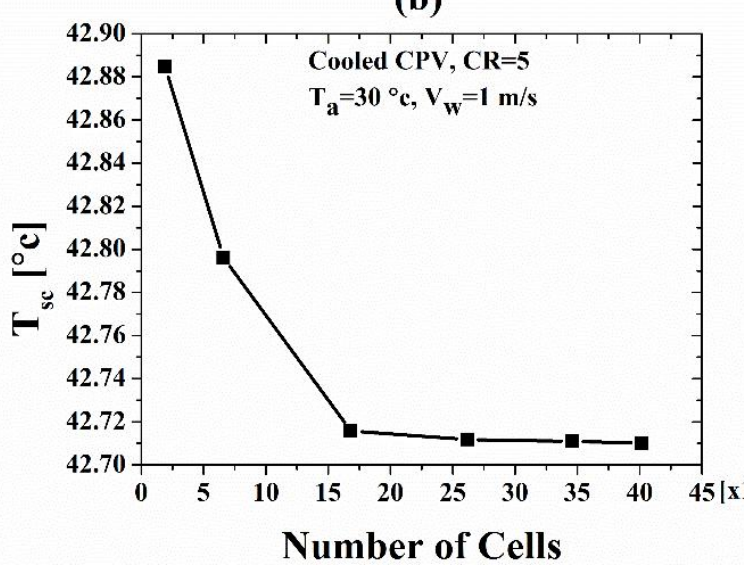

Fig. 3: Mesh independent test for (a) Uncooled PV system and (b) Cooled CPV system.

\subsection{Uncooled PV model validation}

Figures 4-a and $\mathrm{b}$ show the numerical temperature distribution obtained by Zhou et al. (2015) and the current predicted results for the uncooled solar cell respectively. This contours are extracted on a plane located at the mid of the silicon wafer. Comparing both contours show a good agreement of the present model. Further, the uncooled predicted results are compared with the data sheet of the polycrystalline silicon solar cell as given in Zhou et al. (2015). The data sheet reported that the normal operating cell temperature (NOCT) is $45{ }^{\circ} \mathrm{C}$ at $800 \mathrm{~W} / \mathrm{m}^{2}, \mathrm{~T}_{\mathrm{a}}=20{ }^{\circ} \mathrm{C}$ and wind speed of $1 \mathrm{~m} / \mathrm{s}$. Based on the obtained results, it is found that the predicted NOCT is in a good agreement with relative error of about $3.5 \%$. Furthermore, the predicted difference between the cell temperature and the ambient temperature, $\left(\mathrm{T}_{\mathrm{sc}}\right.$ - $\mathrm{T}_{\mathrm{a}}$ ) is compared with that obtained by Zhou et al. (2015). In this part of validation, the ambient temperature is varied from $-10{ }^{\circ} \mathrm{C}$ to $40{ }^{\circ} \mathrm{C}$ and the solar radiation is varied from 400, 700 and $1000 \mathrm{~W} / \mathrm{m}^{2}$. While the wind speed is kept at $1 \mathrm{~m} / \mathrm{s}$ through this comparison. As depicted in Fig. 4-c, there are an excellent agreement between the predicted and numerical results with a maximum difference of $4.2 \%$. 
(a)

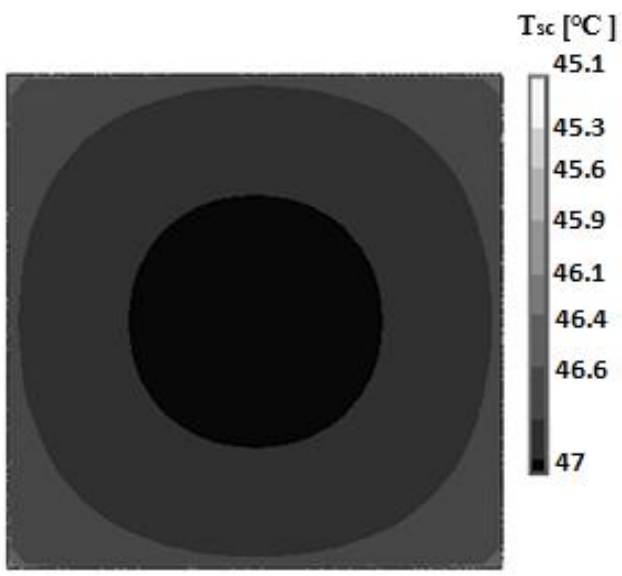

Results of Zhou et al. (2015) (b)

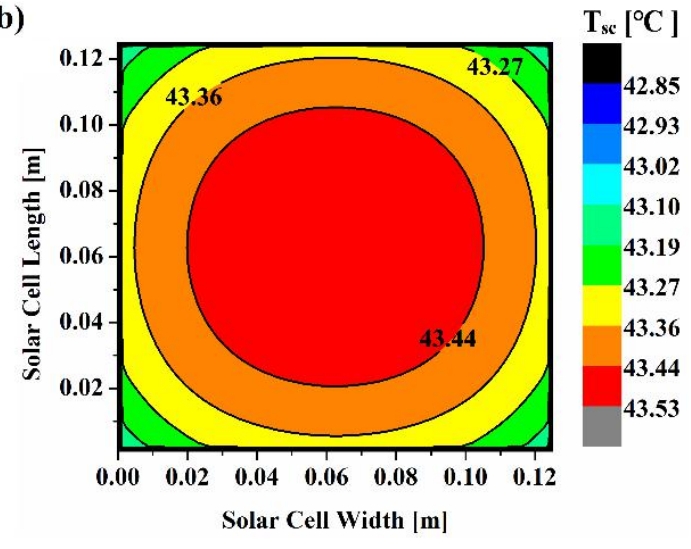

Current predicted

(c)

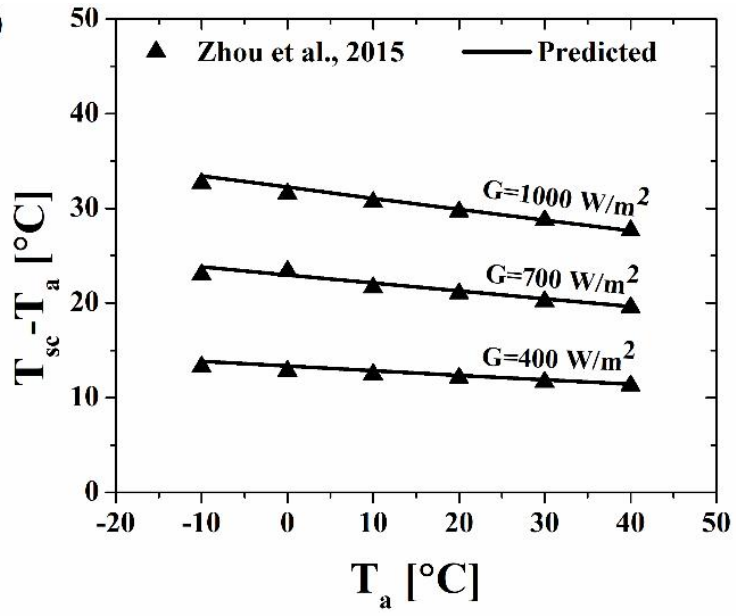

Fig. 4: a) The numerical temperature contour $\left({ }^{\circ} \mathrm{C}\right)$ without cooling at the mid of the silicon wafer (Zhou et al. 2015), (b) current predicted temperature contour and (c) Comparison of current computational results of $\left(\mathrm{T}_{\mathrm{sc}}-\mathrm{T}_{\mathrm{a}}\right)$ with the results reported by Zhou et al. (2015).

\subsection{Cooled microchannel model validation}

The accuracy of predicted MCHS results was checked by comparing the current computational results with the available data obtained by Qu and Mudawar (2002) as indicated in Fig. 5. The experimental model presented by $\mathrm{Qu}$ and Mudawar (2002) was a rectangular MCHS with hydraulic diameter of $86.58 \mu \mathrm{m}$, channel height of $180 \mu \mathrm{m}$, channel width of $57 \mu \mathrm{m}$ and length of $10 \mathrm{~mm}$. The water was used as a cooling liquid. They measured the local temperature along the channel bottom and top walls at $\mathrm{Re}=140$, with inlet temperature of $20^{\circ} \mathrm{C}$ and constant heat flux of $90 \mathrm{KW} / \mathrm{m}^{2}$ that can be produced by the electronic devices. The results showed that there are a good agreement between the predicted and measured local temperatures with around $2.9 \%$ as maximum difference. 


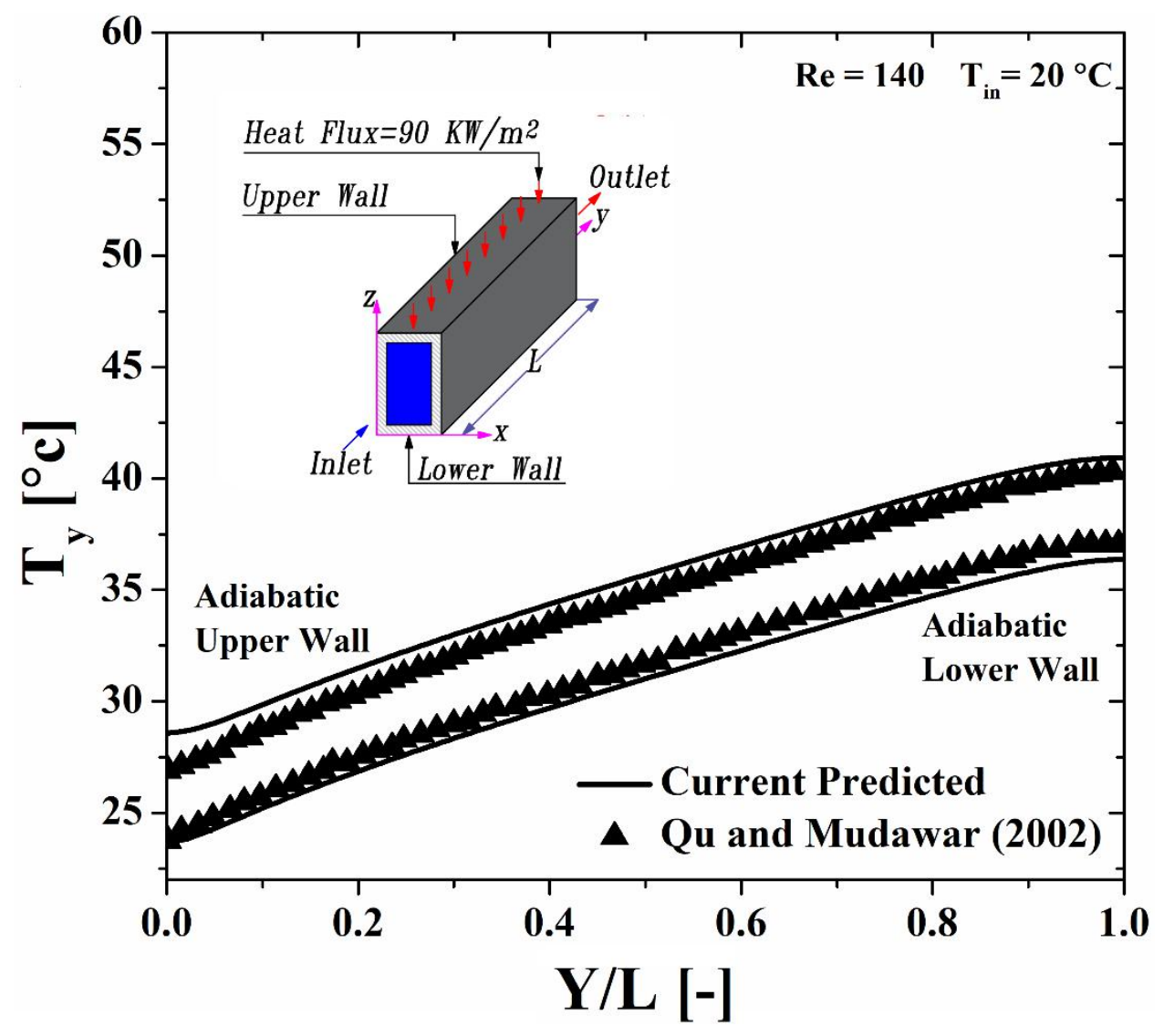

Fig. 5: Comparison of predicted heated wall with numerical results obtained by $\mathrm{Qu}$ and Mudawar (2002) using water as a coolant.

\subsection{PV/T model validation}

This set of validation is verified by comparing the current predicted results with the numerical results reported by Radwan et al. (2017). The computational model presented by Radwan et al. (2017) was a PV system integrated with a rectangular MCHS with a channel height of $0.1 \mathrm{~mm}$, channel width of $126.8 \mathrm{~mm}$ and a length of $63.6 \mathrm{~mm}$. The whole selected dimensions of the MCHS was within the range of previous experimental studies as reported by Tuckerman and Pease (1981). The material of MCHS was aluminum which is the common used material to take its advantages of high thermal conductivity and light weight. Radwan et al. (2017) measured the average temperature at the solar cell layer's central cross-section at mass flow rate of water as a coolant equals $800 \mathrm{~g} / \mathrm{min}, \mathrm{CR}=5$, inlet temperature of $30{ }^{\circ} \mathrm{C}$ and wind velocity $\left(\mathrm{V}_{\mathrm{w}}\right)$ of $1 \mathrm{~m} / \mathrm{s}$. Figure 6 shows the temperature contour for the solar cell temperature on central plane of the solar cell. As indicated at that figure, the cell temperature is around $42.72{ }^{\circ} \mathrm{C}$ that achieved a relative error of 0.05 $\%$ with numerical results obtained by Radwan et al. (2017). 


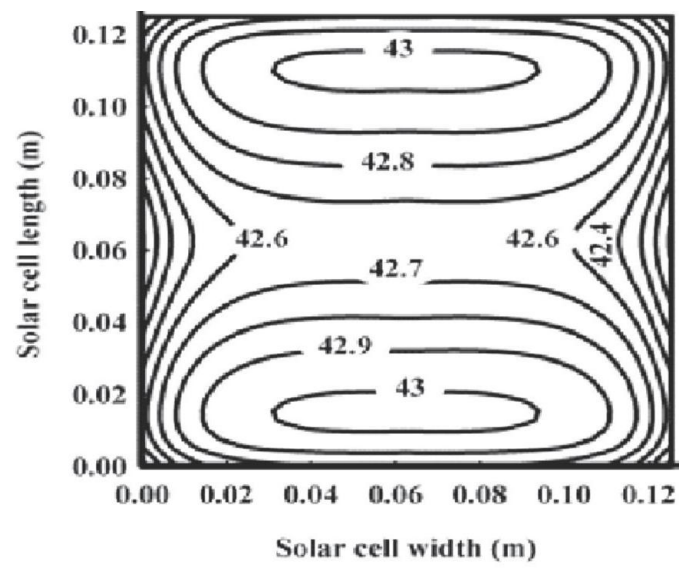

Results of Radwan et al. (2017)

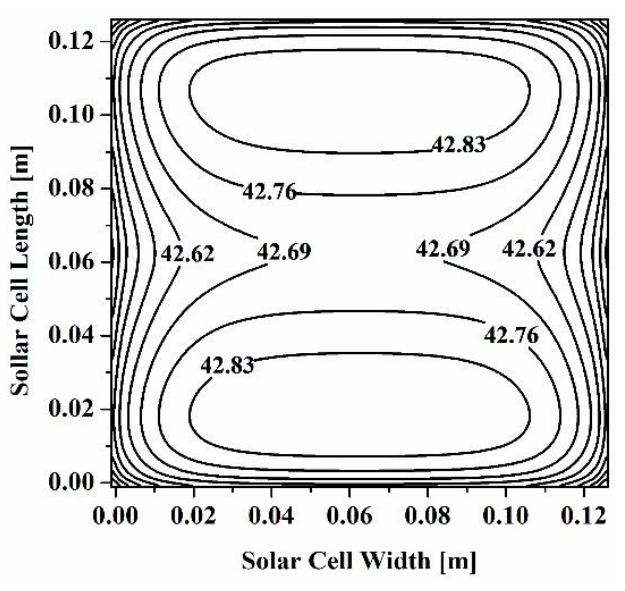

Current predicted

Fig. 6: a) Comparison of predicted temperature contour of solar cell layer's central crosssection with numerical results obtained by Radwan et al (2017).

\section{Results and discussion}

This section will be divided into four subsections, the first subsection deals with the solar cell temperature for uncooled CPV system at different CR. While the second evaluates the uncooled CPV performance. The third gives the obtained results for the cell temperature for $\mathrm{CPV} / \mathrm{T}$ system integrated with MCHS using water as a coolant, cooled PV system,. The fourth summarizes the performance of the water cooled $\mathrm{CPV} / \mathrm{T}$ system. For all obtained results, the ambient temperature and the wind speed are the same. For uncooled study, the CR ranged from 1 to 2.5. While for the cooled $\mathrm{CVP} / \mathrm{T}$, the $\mathrm{CR}$ ranged from 1 to 20 . For all configurations, the coolant mass flowrate was similar and ranged from 200 to $2000 \mathrm{~g} / \mathrm{min}$ to achieve fair comparison.

\subsection{Solar cell temperature of uncooled CPV system:}

For efficient performance for the generic polycrystalline silicon solar cell, the operating temperature should not exceed $85^{\circ} \mathrm{C}$ as reported by Agrawal et al. (2015). Figure 8 represents the temperature contours for the solar cell on a plane located at the midplane of the silicon layer at different $C R$ values of $1,1.5,2$ and $2.5, \mathrm{~T}_{\mathrm{a}}=30$ ${ }^{\circ} \mathrm{C}$ and wind speed of $1 \mathrm{~m} / \mathrm{s}$. It is clear that as the CR increases the cell temperature increases due to increase the received radiation on the solar cell. For instance, at CR of 1, 1.5, 2 and 2.5 the corresponding values of the cell temperature is 49.17 , 61.88, 73.97 and $85.48^{\circ} \mathrm{C}$, respectively. Furthermore, considering Fig. 8d, it is found that the cell temperature around $85.48{ }^{\circ} \mathrm{C}$ at $\mathrm{CR}=2.5$ which recommended for proper use of the solar cell. Consequently, increasing the CR over 2.5 for uncooled CPV system will achieve higher cell temperature and the life time will be decreased. 
Figure 9 shows the maximum average solar cell temperature at different CR. It is clear that the maximum cell temperature significantly increases as the $\mathrm{CR}$ increases. For instance, at $\mathrm{CR}$ of $1,1.5,2$ and 2.5 the corresponding maximum cell temperature is $49.33,62.11,74.27$ and $85.84^{\circ} \mathrm{C}$, respectively.

For preventing the cell degradation and increase the life time of the solar cell, the difference between the maximum and minimum solar cell temperature (the temperature uniformity) should be low. Figure 10 shows the variation of the temperature uniformity at different $\mathrm{CR}$. It can be seen that as the CR increases the temperature difference increases. For example, at $\mathrm{CR}$ of 1, 1.5, 2 and 2.5 the temperature uniformity is $0.49,0.73,0.96$ and $1.19^{\circ} \mathrm{C}$, respectively.
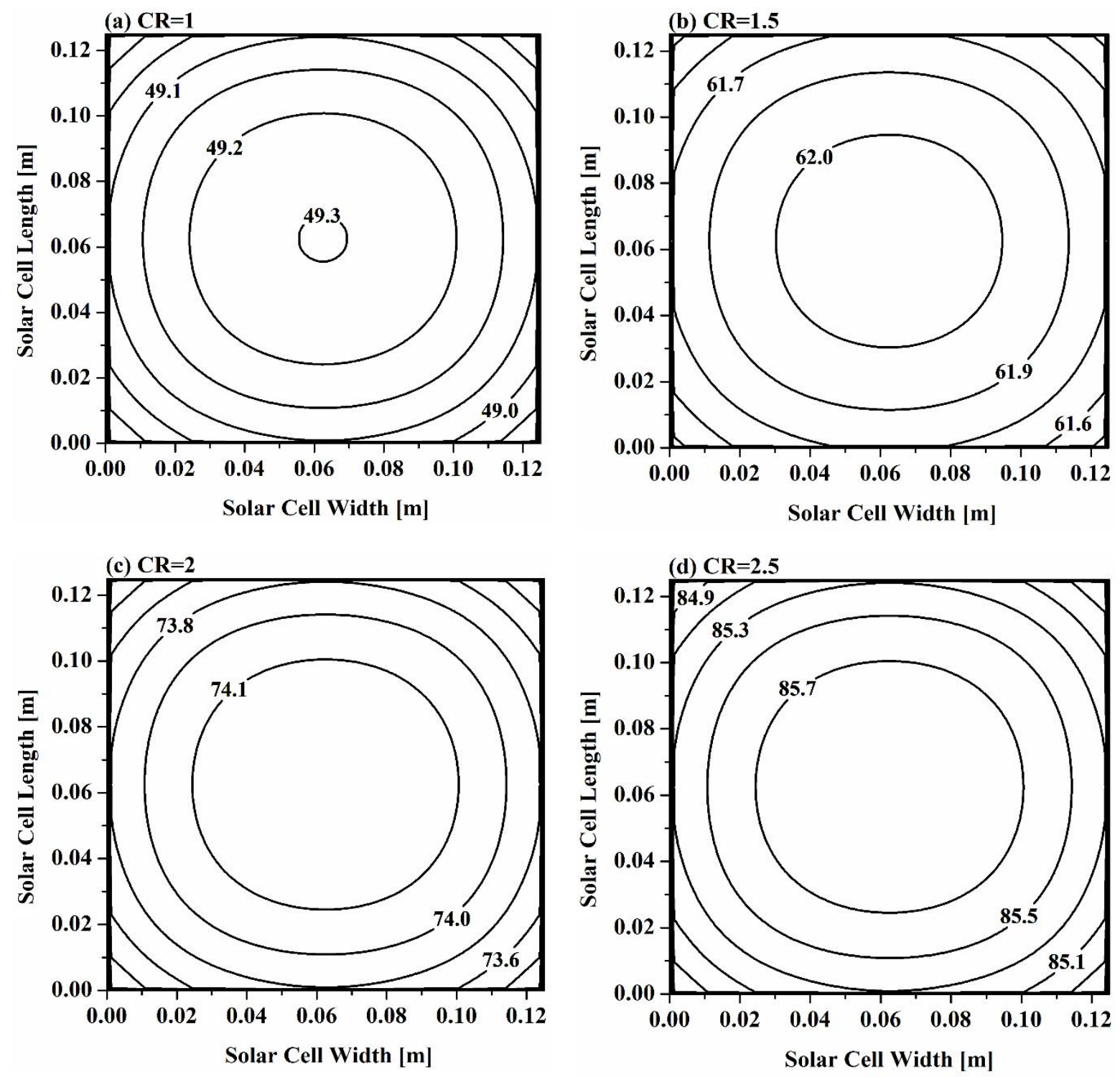

Fig. 8: Temperature $\left({ }^{\circ} \mathrm{C}\right)$ contours for the uncooled solar cell at different low CR. 


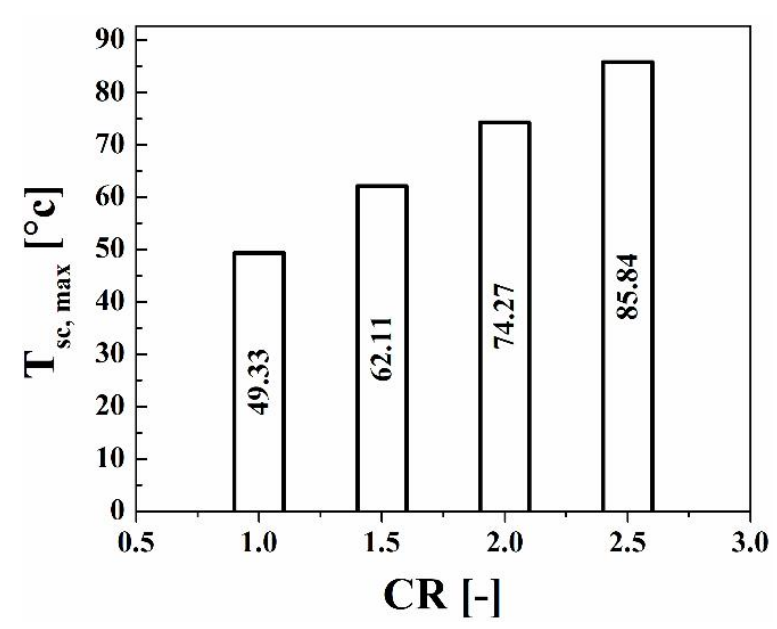

Fig. 9: The maximum average uncooled solar cell temperature at different low CR,

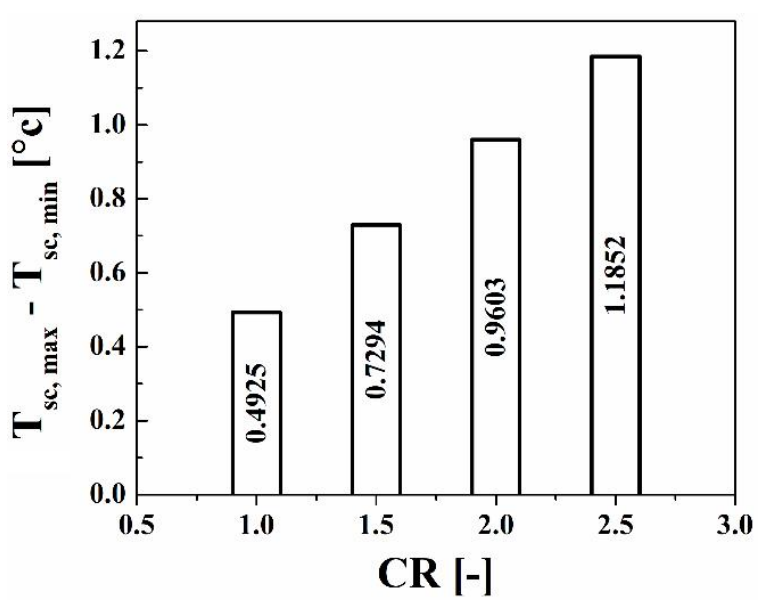

Fig. 10: The Variation of uncooled the silicon layer temperature uniformity at different low CR.

\subsection{Uncooled CPV system performance:}

The main important performance parameters for the CPV systems are the electrical efficiency and the produced electrical power. The variation of the solar cell efficiency and the electrical power of the uncooled CPV system at different CR is indicated in Figs. 11-12, respectively. Figure 11 shows the solar cell efficiency at different $C R, T_{a}=30^{\circ} \mathrm{C}$ and wind speed of $1 \mathrm{~m} / \mathrm{s}$. It is found that as the CR increases the solar cell efficiency significantly decreases due to the significant increasing in the solar cell temperature as reported earlier. For instance, at CR of 1, 1.5, 2 and 2.5 the corresponding values of the solar cell efficiency is $17.8,16.7,15.6$ and 14.6 $\%$, respectively.

In contrary the electrical power is significantly increases as the CR increases due to increasing the amount of the incident radiation on the solar cell as indicated in Fig. 12. For example, at $\mathrm{CR}$ of $1,1.5,2$ and 2.5 , the corresponding values of the produced power is $2.31,3.2,4.03$ and $4.71 \mathrm{~W}$, respectively.

\subsection{Solar cell temperature of cooled CPV/T system:}

The effect of the channel number on the CPV/T system is presented in Figs 13-15. This discussion included the effect of the variation of $\mathrm{N}$ from 26 to 104 on the solar cell temperature of the CPV unit integrated with its own microchannel heat sink. This is determined by exhibiting the temperature distribution along the solar cell in addition to evaluating the maximum solar cell temperature and the temperature 
uniformity at two CR of 10 and 20, and different water mass flowrate of 200, 800 and $2000 \mathrm{~g} / \mathrm{min}$.

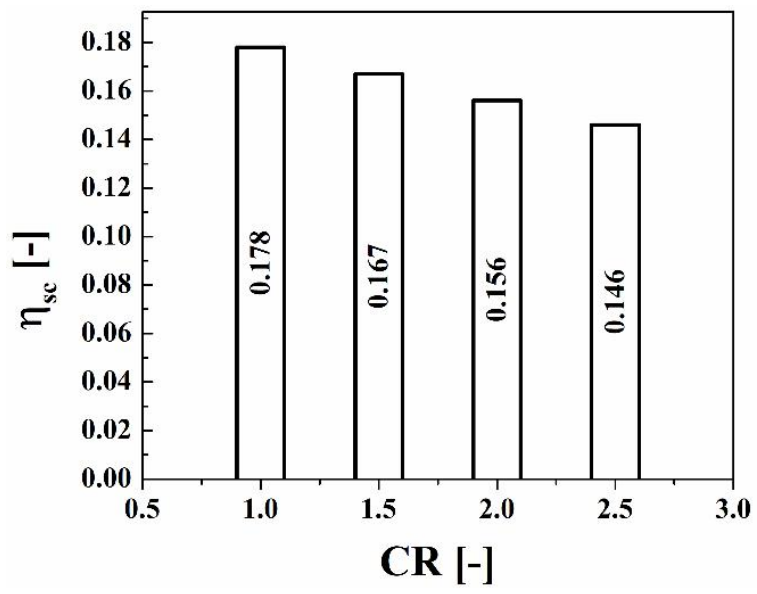

Fig. 11: The variation of the uncooled solar cell efficiency at different low CR.

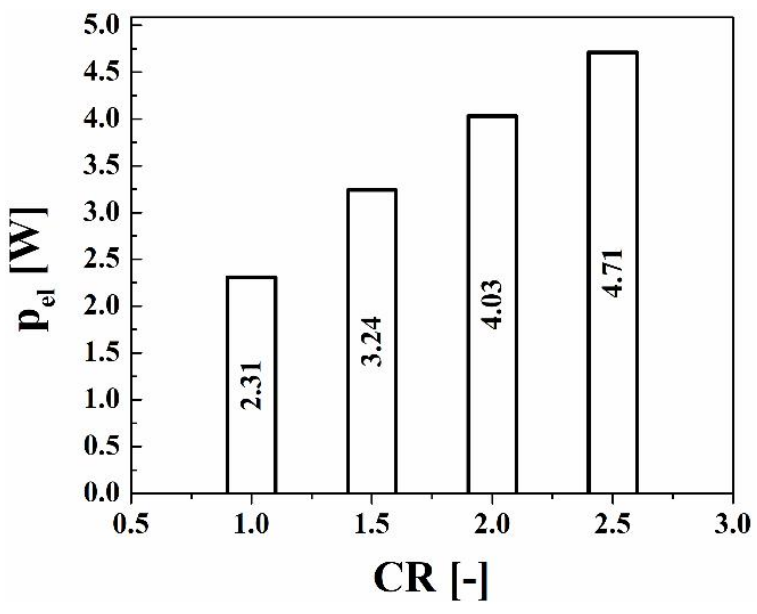

Fig. 12: The variation of the uncooled solar cell electrical power at different low CR.

Figure 13 represents the temperature contours on a midplane located at the middle of the silicon layer to show the effect of $\mathrm{N}$ on the solar cell temperature at $\mathrm{CR}$ of 20 and three water coolant mass flowrate of 200, 800 and $2000 \mathrm{~g} / \mathrm{min}$. the results reveals that increasing $\mathrm{N}$ from 26 to 104 leads to a significant decrease in the solar cell temperature. For instance, at mass flowrate of $200 \mathrm{~g} / \mathrm{min}$, and $\mathrm{N}$ of 26 and 104, the cell temperature significantly decrease from 91.15 to $85.39^{\circ} \mathrm{C}$.

At constant value of the $\mathrm{N}$, it is clear that increasing the mass flowrate leads to a significant reduction in the solar cell temperature due to increase the heat transfer coefficient. For instance, at N of 104 and mass flowrate of 200, 800 and 2000 $\mathrm{g} / \mathrm{min}$, the corresponding values of the solar cell temperature are $85.39,81.99$ and $81.1{ }^{\circ} \mathrm{C}$. Moreover, it is observed that the reduction in the cell temperature decreases as the mass flowrate increases. For example, at $\mathrm{N}$ of 52 , increasing the mass from 200 to $800 \mathrm{~g} / \mathrm{min}$ leads to a reduction in the cell temperature reached to $3.9^{\circ} \mathrm{C}$. While increasing the mass flowrate from 800 to $2000 \mathrm{~g} / \mathrm{min}$ achieved 1.22 ${ }^{\circ} \mathrm{C}$ reduction in the cell temperature. This is most likely due to the saturated level of heat extracted from the solar cell achieved at higher coolant mass rates, as explained by Du et al. (2012).

The maximum temperature of the solar cell is one of the most important parameters that must be monitored to achieve popper functioning for the solar cell. Figure 14 shows the effect of $\mathrm{N}$ on the maximum temperature of the solar cell. As indicated in Fig. 14a and $\mathrm{b}$ increasing $\mathrm{N}$ leads to a significant decrease in the solar cell temperature. For instance, at $\mathrm{CR}=20$, mass flowrate of $200 \mathrm{~g} / \mathrm{min}$ and $\mathrm{N}$ of 26,52 , 78 and 104 , the obtained maximum cell temperature is $93.2,90.4,89.5$ and $87.3{ }^{\circ} \mathrm{C}$, 
respectively. As mentioned before, for proper operation of the solar cell, the cell temperature shouldn't be exceeds $85{ }^{\circ} \mathrm{C}$. Increasing the mass flowrate to 2000 $\mathrm{g} / \mathrm{min}$ achieves better performance where for all configurations the maximum cell around or lower than $85^{\circ} \mathrm{C}$. For instance, at $\mathrm{CR}=20$, mass flowrate of $2000 \mathrm{~g} / \mathrm{min}$ and $\mathrm{N}$ of $26,52,78$ and 104 , the obtained maximum cell temperature is $85.3,84.1$, 83.6 and $81.7^{\circ} \mathrm{C}$, respectively.

Figure 15a and $\mathrm{b}$ show the difference between the maximum and minimum solar cell temperature versus $\mathrm{N}$ at different mass flowrate and two options of $\mathrm{CR}$ of 10 and 20. As indicated in these figures, increasing $\mathrm{N}$ significantly decreases the temperature uniformity except the increasing in $\mathrm{N}$ from 52 to 78 at both mass flowrate of $200 \mathrm{~g} / \mathrm{min}$ and $2000 \mathrm{~g} / \mathrm{min}$. Where slight increase in the temperature uniformity is obtained. For instance, at CR of 20, mass flowrate of $2000 \mathrm{~g} / \mathrm{min}$ and $\mathrm{N}$ of 26,52, 78 and 104, the corresponding values of the temperature uniformity are $3.12,2.84,2.91$ and $2.67{ }^{\circ} \mathrm{C}$, respectively. Moreover, increasing the mass flowrate significantly reduces the temperature uniformity for all options of the CR. For example, at CR of 10, N equals 26 and mass flowrate of 200,800 and $2000 \mathrm{~g} / \mathrm{min}$, the obtained values of the temperature uniformity are $2.97,1.94$ and $1.51{ }^{\circ} \mathrm{C}$, respectively.

\subsection{CPV/T system performance:}

The main important parameters to assess any $\mathrm{CPV} / \mathrm{T}$ integrated with MCHS are solar cell efficiency, solar cell electrical power, friction power, net gained electrical power, thermal power and thermal efficiency. These parameters are summarized and presented in Figs.16-21.

Figure 16a and $\mathrm{b}$ shows the effect of $\mathrm{N}$ on the solar cell efficiency at different options of CR of 10 and 20, water mass flowrate of 200,800 and $2000 \mathrm{~g} / \mathrm{min}$, $\mathrm{T}_{\mathrm{a}}=30{ }^{\circ} \mathrm{C}$ and wind speed of $1 \mathrm{~m} / \mathrm{s}$. The results indicated that for all CR, the solar cell efficiency significantly increases as $\mathrm{N}$ increases due to the significant decrease in the solar cell temperature as mentioned in above section. For example, at $\mathrm{CR}=10$, mass flowrate of $200 \mathrm{~g} / \mathrm{min}$ and $\mathrm{N}$ of 26, 52, 78 and 104, the corresponding values of the solar cell efficiency are $16.88,16.99,17.00$ and $17.10 \%$ respectively. It is also found that increasing the mass flowrate significantly increase the solar cell efficiency at low range of mass flowrate then the effect of increasing the mass flow rate has no significant effect. For instance, at $\mathrm{CR}=20$ and $\mathrm{N}$ equals 104 and mass flowrate of 200,800 and $2000 \mathrm{~g} / \mathrm{min}$, the corresponding values of the solar cell efficiency are $14.56,14.87$ and $14.95 \%$, respectively. With $0.31 \%$ increasing in the cell efficiency for increasing the mass flowrate from 200 to $800 \mathrm{~g} / \mathrm{min}$ and $0.08 \%$ increasing in the cell efficiency when the mass flowrate increases from 800 to 2000 $\mathrm{g} / \mathrm{min}$. Based on the obtained results, increasing the CR significantly reduces the solar cell efficiency due to increase the solar cell temperature. 
(a)
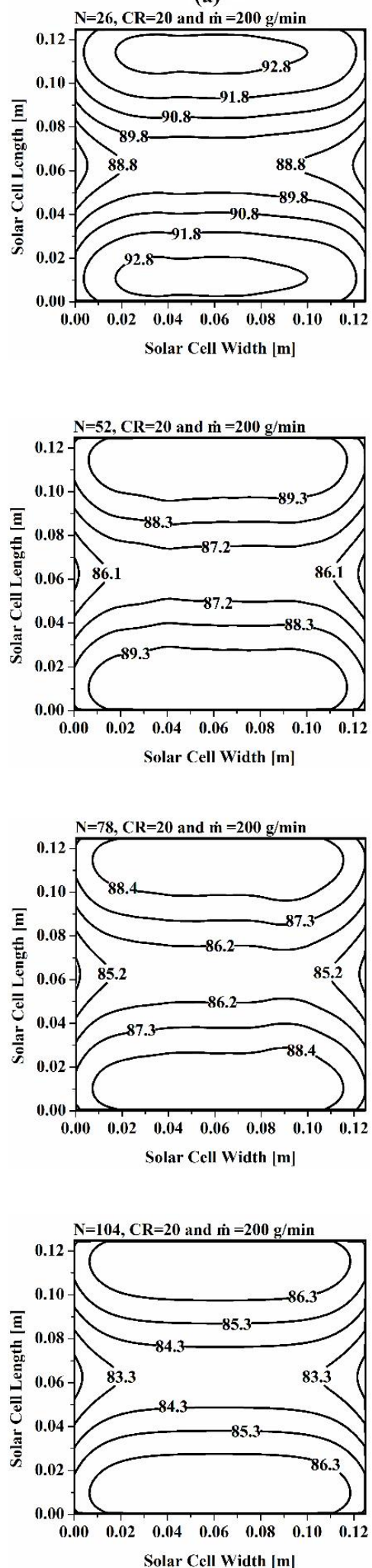

(b)

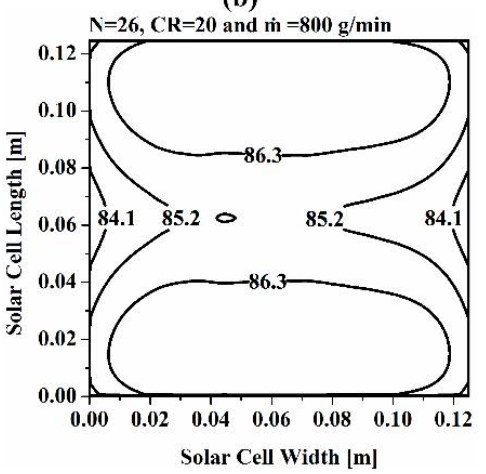

$\mathrm{N}=52, \mathrm{CR}=20$ and $\dot{\mathrm{m}}=\mathbf{8 0 0} \mathrm{g} / \mathrm{min}$
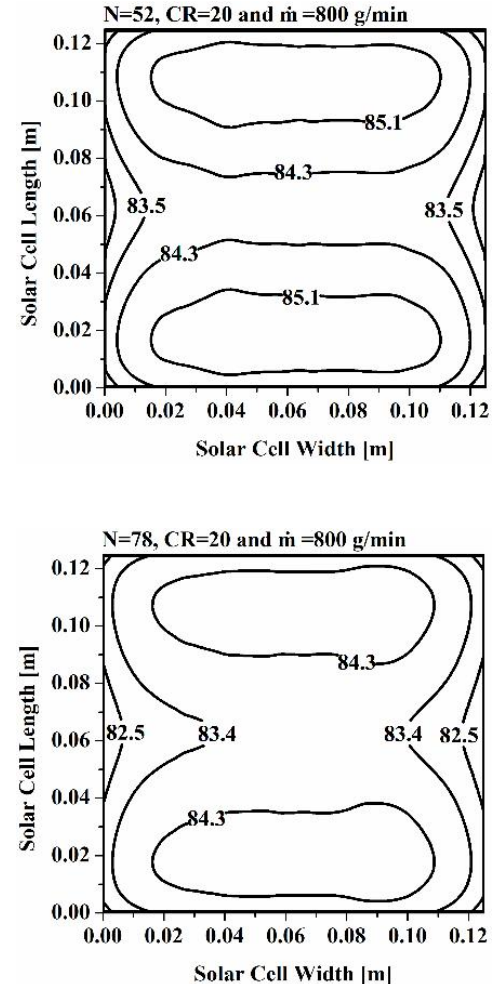

Solar Cell Width $|\mathrm{m}|$

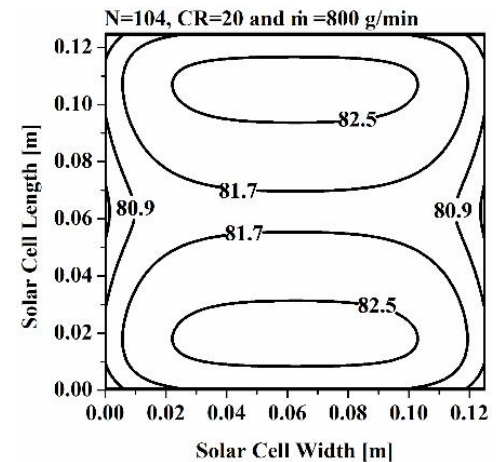

(c)
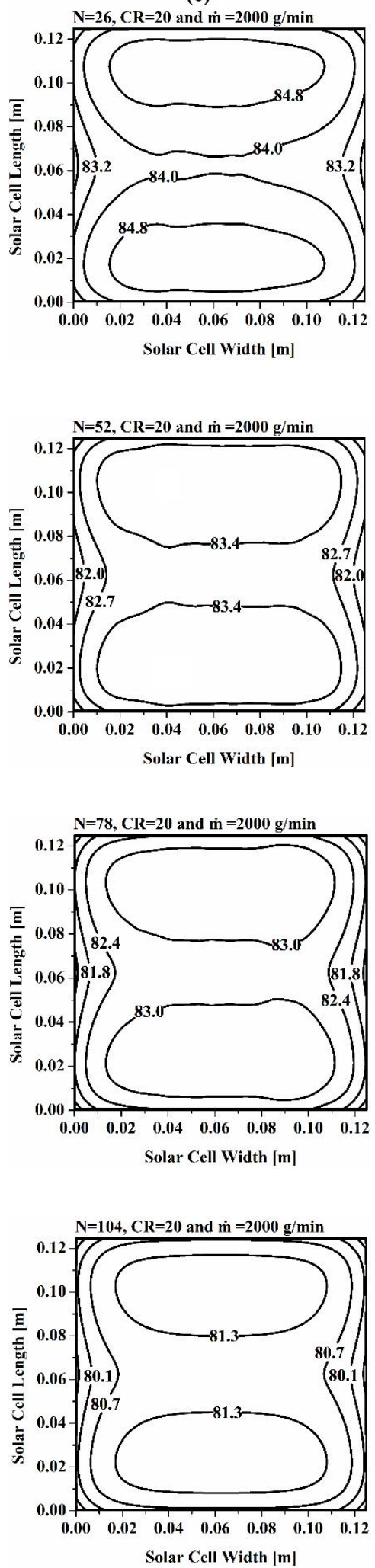
Fig. 13: Temperature $\left({ }^{\circ} \mathrm{C}\right)$ contours for the water cooled solar cell for different $\mathrm{N}$ and water mass flowrate, at $\mathrm{CR}=20$.

(a)

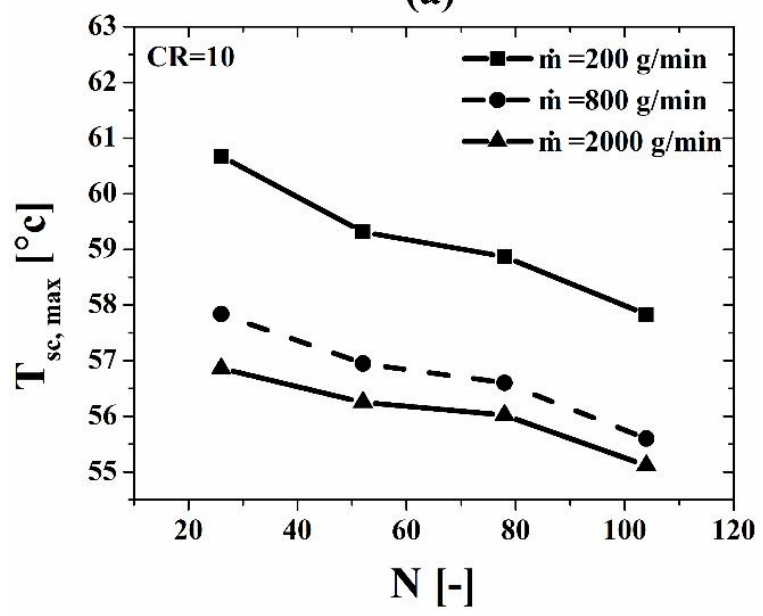

(b)

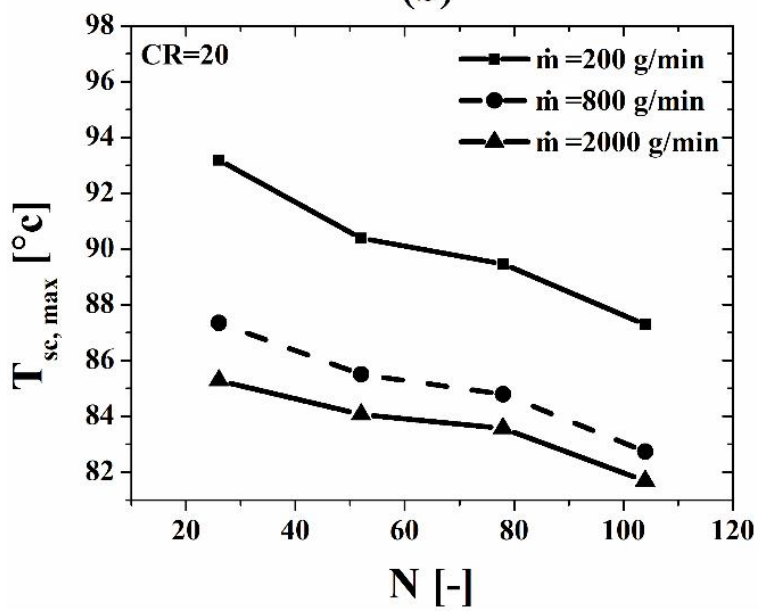

Fig. 14: The maximum average concentrated solar cell temperature for different $\mathrm{N}$ and water mass flowrate for (a) $\mathrm{CR}=10$, and (b) $\mathrm{CR}=20$.

(a)

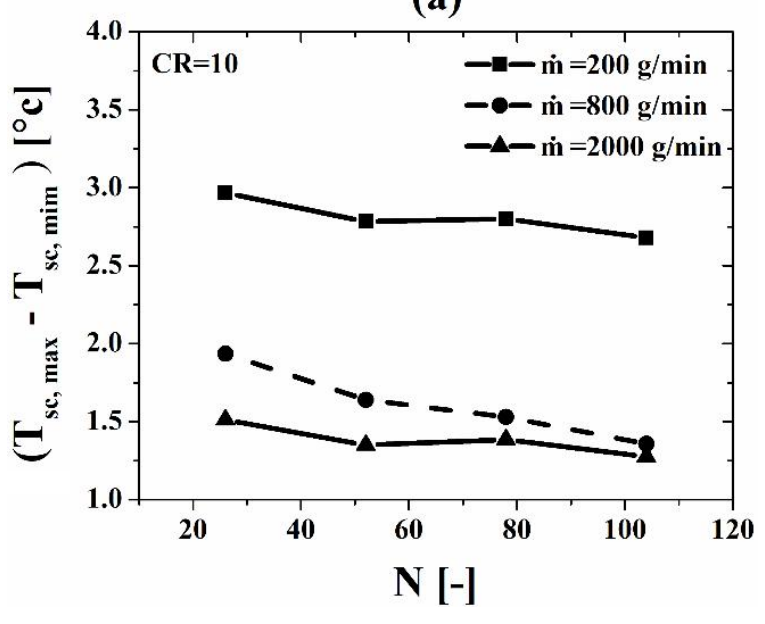

(b)

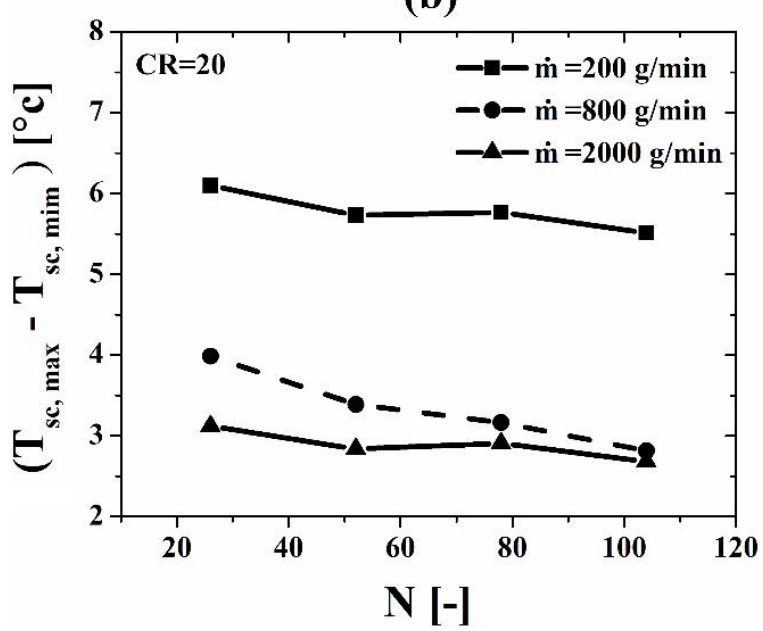

Fig. 15: The variation of the concentrate silicon cell layer temperature uniformity for different $\mathrm{N}$ and water mass flowrate for (a) $\mathrm{CR}=10$, and (b) $\mathrm{CR}=20$.

Figure $17 \mathrm{a}$ and $\mathrm{b}$ shows the effect of $\mathrm{N}$ on the produced power at different $\mathrm{CR}$ and mass flowrate. Based on the obtained results, it is found that for all CR, as $\mathrm{N}$ increases the electrical power significantly increases. For instance at $\mathrm{CR}=20$ and mass flowrate of $800 \mathrm{~g} / \mathrm{min}$ and $\mathrm{N}$ of $26,52,78$ and 104, the corresponding values of the electrical power are 37.5, 37.88, 38.04 and $38.48 \mathrm{~W}$, respectively. From these figures, it is also observed that for all CR and constant N, increasing the mass flowrate leads to a significant increase in the produced power. For example, at $\mathrm{CR}=$ 
20 and $\mathrm{N}$ equals 26 and mass flowrate of 200,800 and $2000 \mathrm{~g} / \mathrm{min}$ the corresponding values are $36.3,37.5$ and $38 \mathrm{~W}$, respectively.

It is also observed that as the $\mathrm{CR}$ increases the solar cell electrical power significantly increases where at constant $\mathrm{N}$ of 104 and constant mass flowrate of $200 \mathrm{~g} / \mathrm{min}$ and CR equals 10 and 20, the produced electrical power is 22.16 and $37.69 \mathrm{~W}$, respectively
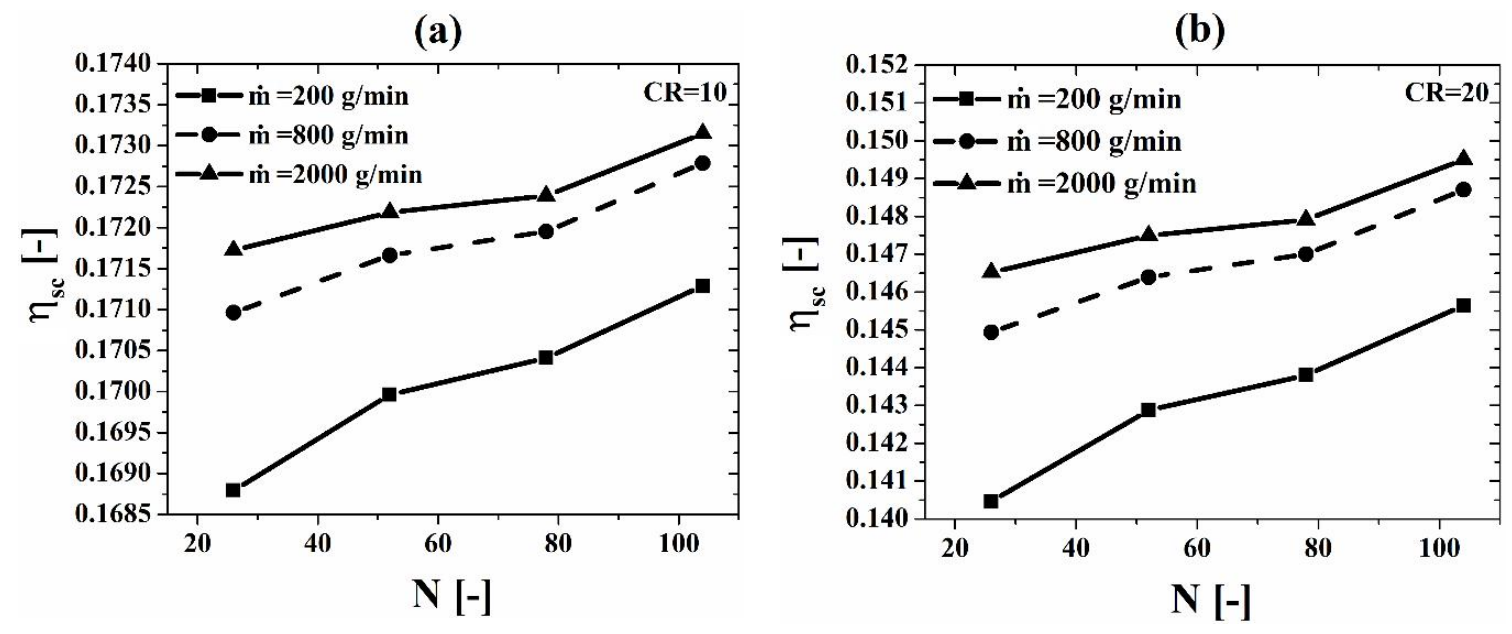

Fig. 16: The solar cell efficiency versus $N$ at different mass flowrate for (a) $C R=10$ and (b) $\mathrm{CR}=20$.

(a)

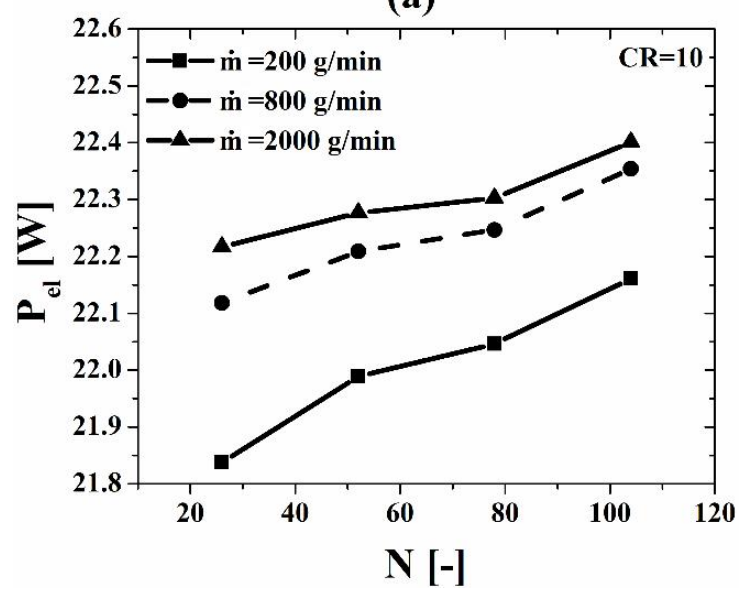

(b)

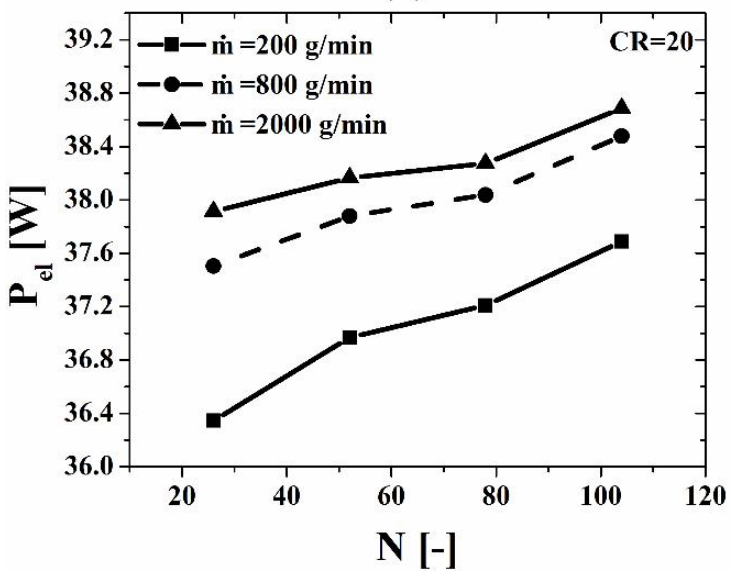

Fig. 17: The cooled solar cell electrical power versus $\mathrm{N}$ at different water mass flowrate for (a) $\mathrm{CR}=10$ and (b) $\mathrm{CR}=20$.

The penalty of the MCHS is the extracted fraction of the produced power to overcome the friction in the microchannels. As this fraction of consumed power decreases the net gained power increases. Figure 18a and $b$ show the effect of the variation of $\mathrm{N}$ on the friction power at different $\mathrm{CR}$ and mass flowrate. The results indicated that for all $\mathrm{CR}$ increasing $\mathrm{N}$ significantly reduces the friction power at the 
highest mass flowrate of $2000 \mathrm{~g} / \mathrm{min}$. While at the mass flowrate of 200 and 800 $\mathrm{g} / \mathrm{min}$, there is no significant effect is achieved. For example, at $\mathrm{CR}=20$ and mass flowrate of $2000 \mathrm{~g} / \mathrm{min}$ and $\mathrm{N}$ of 26, 52, 78 and 104, the corresponding values of the friction power are $8.00,6.75,6.29$ and $6.10 \mathrm{~W}$, respectively with nearly about 2 $\mathrm{W}$ reduction in the friction power by increasing $\mathrm{N}$ from 26 to 104 . While at $\mathrm{CR}=20$ and mass flowrate of $200 \mathrm{~g} / \mathrm{min}$ and $\mathrm{N}$ of 26, 52, 78 and 104, the corresponding values of the friction power are $0.05,0.0499,0.0498$ and $0.0497 \mathrm{~W}$, respectively with nearly about $0.000416 \mathrm{~W}$ reduction for increasing $\mathrm{N}$ from 26 to 104 .

Finally, it is clear that as the water mass flowrate increases the friction power significantly increases. For example, at $\mathrm{CR}=10, \mathrm{~N}$ of 26 and water mass flowrate of $200,800,2000 \mathrm{~g} / \mathrm{min}$ the evaluated values of the friction power are $0.05,1.03$ and $8.1 \mathrm{~W}$, respectively.

(a)

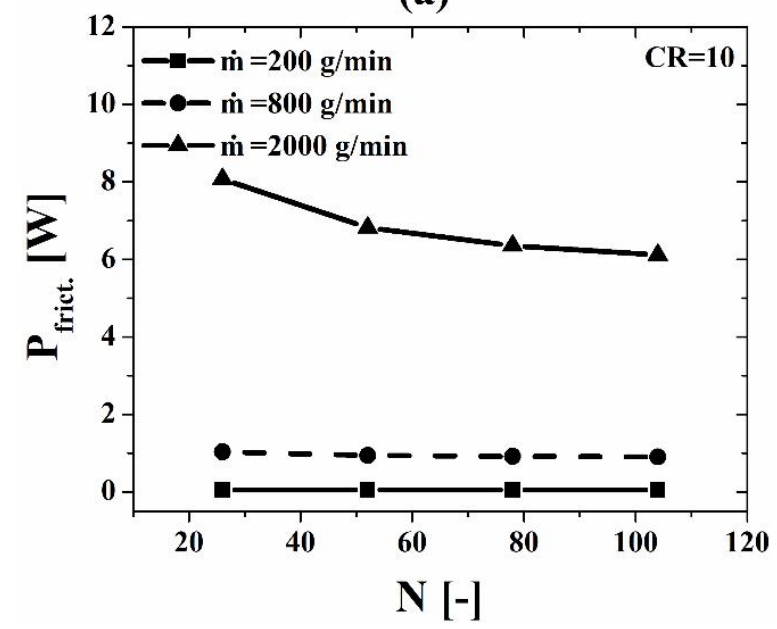

(b)

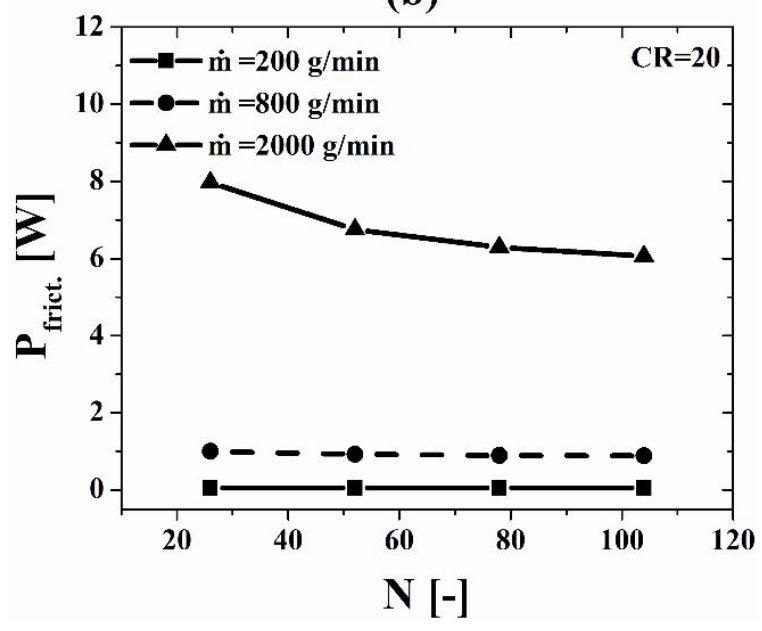

Fig. 18: The effect of $N$ variation on the friction power for different water mass flowrate for (a) $\mathrm{CR}=10$ and (b) $\mathrm{CR}=20$.

Figure 19 shows the effect of $\mathrm{N}$ on the net gained power at different $\mathrm{CR}$ and water mass flowrate. Based on the obtained results from Figs. 19a and b, it is clear that the increasing in $\mathrm{N}$ leads to a significant increase in the net power of the CPV/T system at highest mass flowrate of $2000 \mathrm{~g} / \mathrm{min}$ compared to the lower mass flowrate of 200 and $800 \mathrm{~g} / \mathrm{min}$. For example, at $\mathrm{CR}=20$, mass flowrate of 2000 $\mathrm{g} / \mathrm{min}$ and $\mathrm{N}$ of $26,52,78$ and 104 , the corresponding values of the net power are $29.94,31.42,31.98$ and $32.63 \mathrm{~W}$, respectively. While at $\mathrm{CR}=20$, mass flowrate of $200 \mathrm{~g} / \mathrm{min}$ and $\mathrm{N}$ of $26,52,78$ and 104 , the corresponding values of the net power are $36.3,36.92,37.16$ and $37.64 \mathrm{~W}$, respectively. From these results also it is found that the maximum net gained power is achieved at lower mass flowrate due to lower achieved friction power. For example, at $\mathrm{CR}=20, \mathrm{~N}$ of 104 and mass flowrate of 200, 800 and $2000 \mathrm{~g} / \mathrm{min}$, the corresponding values of the net power are $37.64,37.59$ and $32.63 \mathrm{~W}$, respectively. 
(a)

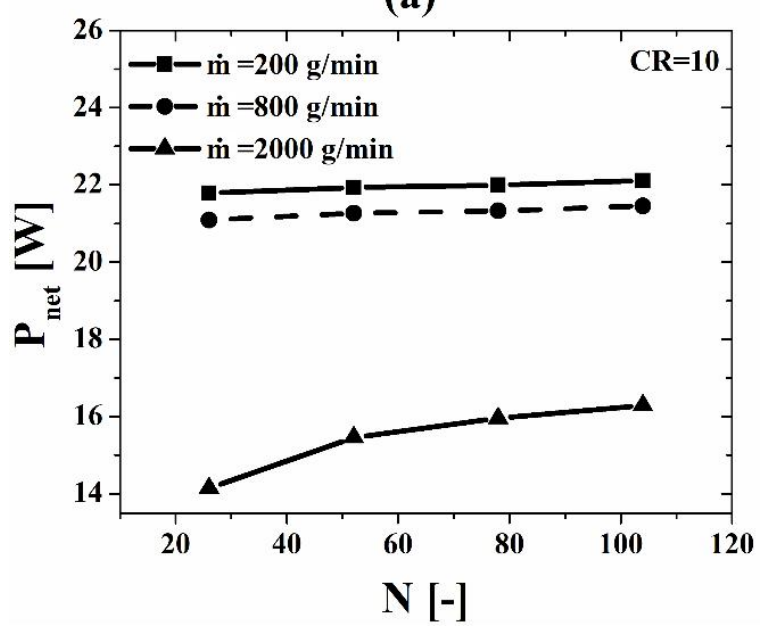

(b)

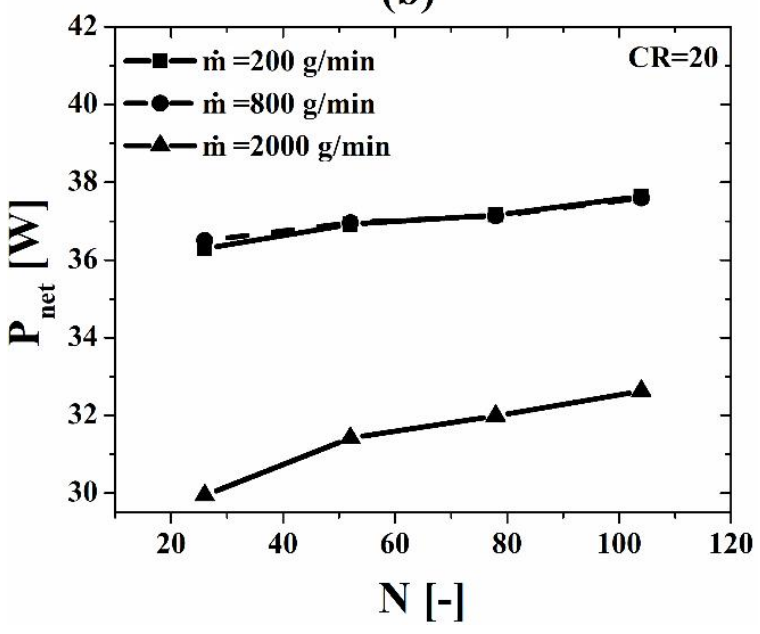

Fig. 19: The effect of $\mathrm{N}$ variation on the net gained power for different mass flowrate for (a) $\mathrm{CR}=10$ and (b) $\mathrm{CR}=20$.

Figure 20 shows the variation in the useful thermal power gained by cooling PV cells that achieved by the changing in $\mathrm{N}$ at different water mass flowrate and $\mathrm{CR}$. Based on the obtained results, increasing $\mathrm{N}$ significantly decrease the thermal power. For example, at $\mathrm{CR}=20$, mass flowrate of $2000 \mathrm{~g} / \mathrm{min}$ and $\mathrm{N}$ of $26,52,78$ and 104, the corresponding values of the thermal power are 224, 196, 179 and 168 $\mathrm{W}$, respectively. For all CR options, it is clear that increasing the mass flowrate significantly increases the thermal power due to increase the heat transfer coefficient that leads to increase absorbed thermal energy by the cooling liquid.

Figure 21 represents the effect of $\mathrm{N}$ on the thermal efficiency for different mass flowrate and CR. It is found that, increasing $\mathrm{N}$ significantly decreases the thermal efficiency due to increase the electrical efficiency that reduce the amount of extracted heat be the coolant. As indicated at Figs. 21a, b and c, increasing the CR significantly increases the thermal efficiency due to increase the amount of the solar radiation that received by the solar cell. For instance, at $\mathrm{N}$ equals 26 and mass flowrate of $2000 \mathrm{~g} / \mathrm{min}$, increasing the CR from 1 to 20 leads to increase the thermal efficiency from 59.7 to $71.7 \%$.
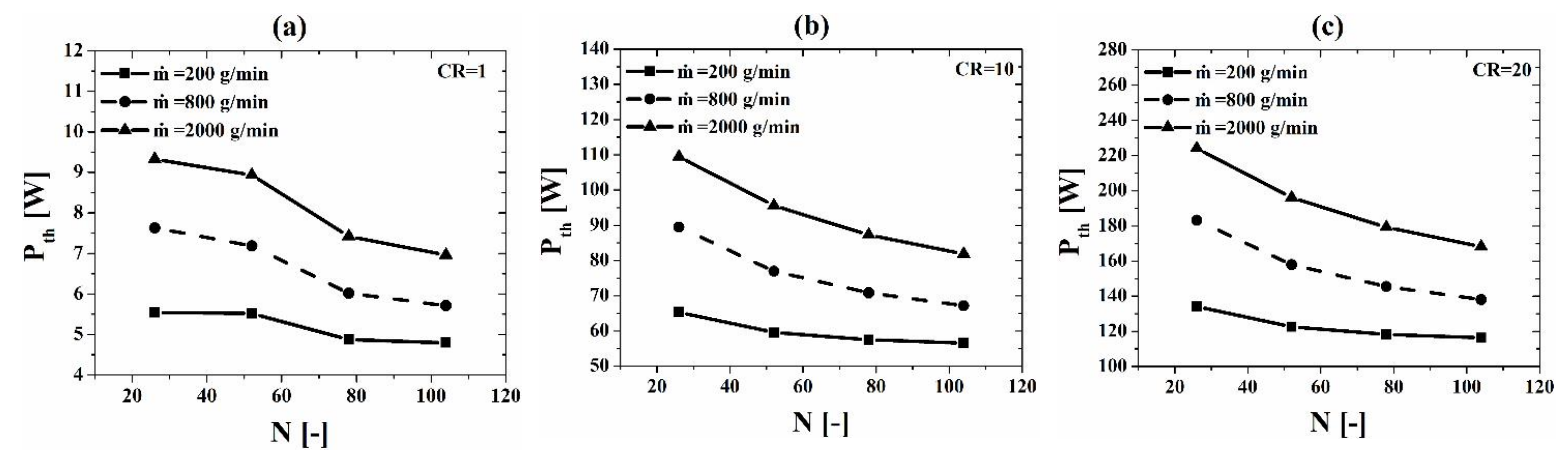

Fig. 20: The thermal power at different water mass flowrate and CR. 
(a)

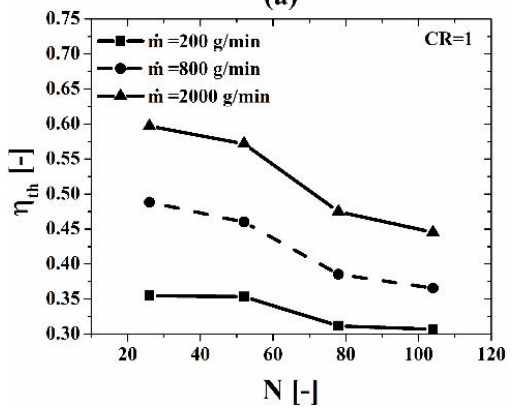

(b)

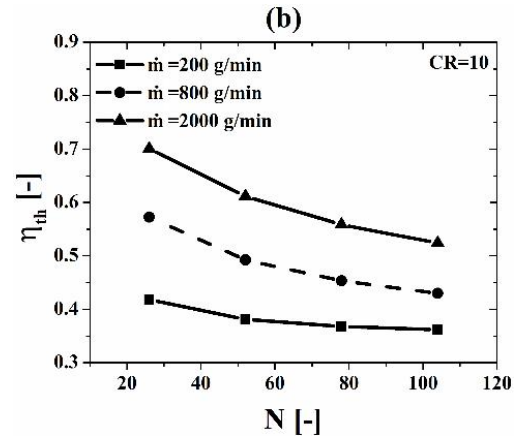

(c)

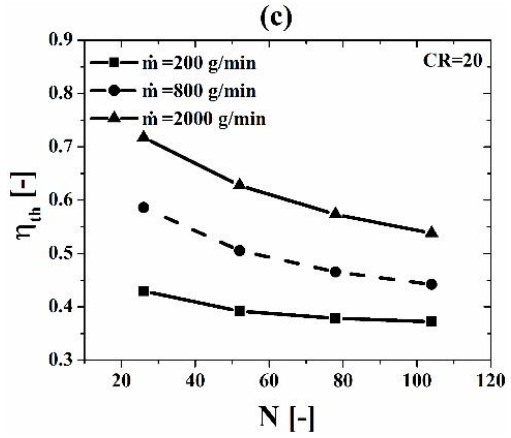

Fig. 21: The thermal efficiency at different water mass flowrate and CR.

\section{Conclusions}

A computational model was utilized to simulate a three dimensional fluid flow and heat transfer for uncooled CPV and cooled CPV integrated with MCHS filled with water as a coolant. Based on the present computational study, the following results may be concluded:

- The maximum CR can be used for the uncooled CPV system should not exceed 2.5 which resulted in cell temperature around $85.48{ }^{\circ} \mathrm{C}$. That value is slightly higher than the maximum allowable operating temperature recommended for proper functioning of the solar cell.

- As the CR increases for uncooled and cooled CPV systems, the cell efficiency decreases due to the increase of the cell temperature, while the net gained electrical power increases;

- For the study of the cooled CPV/T, increasing N significantly decrease the cell temperature due to increase the heat transfer area;

- Increasing the water mass flowrate enhance the cooling process up to limit after that unremarkable temperature reduction is observed.

Appendix A. The following equations are used in the current study to estimate the performance parameters.

$P_{\text {frict. }}=\Delta P \cdot \frac{\dot{m}}{\rho_{\text {in }}}$

$\Delta P=f \frac{L_{c h} \rho_{i n} v_{i n}^{2}}{2 D_{h}}$ 


$$
\begin{aligned}
& C R=\frac{G(t)}{G_{r e f}}, G_{r e f}=1000 \mathrm{~W} / \mathrm{m}^{2} \\
& P_{\text {net }}=P_{e l}-P_{\text {frict. }} \\
& \eta_{s c}=\frac{P_{t h}}{G(t) A_{s c}}
\end{aligned}
$$

\section{Nomenclatures}
A Solar cell Area $\left(\mathrm{m}^{2}\right)$
c Specific heat capacity $(\mathrm{J} / \mathrm{kg} \mathrm{k})$
$D_{h} \quad$ Hydraulic diameter of the fluid flow channel (m)
$\mathrm{G}(\mathrm{t}) \quad$ Net concentrated solar radiation $\left(\mathrm{W} / \mathrm{m}^{2}\right)$
$\mathrm{H} \quad$ Height or thickness (m)
k Thermal conductivity (W/m K)
L Microchannel length and solar cell length (m)
$\dot{m} \quad$ Cooling fluid mass flow rate $(\mathrm{kg} / \mathrm{s})$
$\mathrm{N} \quad$ Number of cooling channels
P Pressure (Pa), and Power (W)
Re Reynolds number
$\mathrm{T} \quad$ Temperature $\left({ }^{\circ} \mathrm{C}\right)$
$\mathrm{u}, \mathrm{v}, \mathrm{w} \quad$ Velocity in $\mathrm{x}, \mathrm{y}$, and $\mathrm{z}$ direction $(\mathrm{m} / \mathrm{s})$

W Width, thickness of fin between flow channel and neighboring flow channel (m)

$\mathrm{x}, \mathrm{y}, \mathrm{z} \quad$ Cartesian coordinates

\section{Greek Symbols}

$\alpha$

Absorptivity 
$\beta \quad$ Solar cell temperature coefficient $(1 / \mathrm{K})$

$\varepsilon \quad$ Emissivity

$\tau \quad$ Transmissivity

$\mu \quad$ Dynamic viscosity $(\mathrm{kg} / \mathrm{m} \mathrm{s})$

$\sigma \quad$ Stephan-Boltzmann constant $\left(5.67 \times 10^{-8}\left(\mathrm{~W} /\left(\mathrm{m}^{2} \mathrm{~K}^{4}\right)\right)\right.$

$\rho \quad$ Fluid density $\left(\mathrm{kg} / \mathrm{m}^{3}\right)$

$\delta \quad$ Thickness (m)

$\lambda \quad$ Molecular mean free path (m)

$\eta \quad$ Solar cell and thermal efficiency

\section{Subscript}

Ambient

b Back sheet or tedlar

ch Channel

conv, g- Convection loss from glass to ambient

a

el Electrical

f Fluid and fin spacing between the flow channel and the neighboring flow channel

fric. Friction

g Glass

in Inlet

net Net

out Outlet

rad, g-s Radiation loss from glass to sky temperature

ref Reference condition, $\mathrm{G}=1000 \mathrm{~W} / \mathrm{m}^{2}, \mathrm{~T}=25^{\circ} \mathrm{C}$

s $\quad$ Sky

sc $\quad$ Silicon wafer

th Thermal 
Wall and Wind
Abbreviations
CPV Concentration photovoltaic system
$\mathrm{CPV} / \mathrm{T} \quad$ Concentration photovoltaic thermal system
MCHS Microchannel heat sink
NOCT Normal operating cell temperature
PV Photovoltaic

\section{References}

Adham, A.M., Mohd-Ghazali, N. and Ahmad, R. 2016. Optimization of nanofluidcooled microchannel heat sink. Thermal Science, 20(1), pp. 109-118.

Ahmed, M and Eslamian, M. 2014. Natural convection in a differentially-heated square en- closure filled with a nanofluid: significance of the thermophoresis force and slip/ drift velocity. Int Commun Heat Mass Transfer; 58, pp. 1-11.

Anderson, W.G., Dussinger, P.M., Sarraf, Tamanna, S. and Hoffman, R. 2008. Heat Pipe Cooling of Concentrating Photovoltaic (CPV) Systems, in: 6th Int. Energy Convers. Eng. Conf., IEEE, pp. 1-6.

Baloch, A. A. B., Bahaidarah, H. M. S., Gandhidasan, P., and Al-Sulaiman, F. A. 2015. Experimental and numerical performance analysis of a converging channel heat exchanger for PV cooling. Energy Conversion and Management, 103, pp. 1427.

Chaudhari, K.S. and Walke, P. V. 2014. Applications of nanofluid in solar energy A Review. International journal of engineering research and technology, 3(3), pp. $460-463$.

Du, B. 2012. Water cooled concentrated photovoltaic system. Renewable and Sustainable Energy Reviews, 16(9), pp. 6732-6736.

Dehghan, M., Daneshipour, M., Valipour, MS., Rafee, R. and Saedodin, S. 2015. Enhancing heat transfer in microchannel heat sinks using converging flow passages. Energy Convers Manage; 92, pp. 244-50. 
El, M., Slimani, A., Amirat, M., Kurucz, I., Bahria, S. and Hamidat, A. 2017. A detailed thermal-electrical model of three photovoltaic/thermal (PV/T) hybrid air collectors and photovoltaic (PV) module: comparative study under Algiers climatic conditions. Energy Convers Manage; 133, pp. 458-76.

Geng, W.G. 2012. Numerical and experimental study on cooling highconcentration photovoltaic cells with oscillating heat pipe. International Journal of Low-Carbon Technologies, 7(3), pp. 168-173.

Jayakumar, JS, Mahajani, SM, Mandal, JC, Vijayan, PK and Bhoi, R. 2008. Experimental and CFD estimation of heat transfer in helically coiled heat exchangers. Chemical Engineering Research and Design; 86, pp. 221-32.

Joshi, A., Tiwari, A., Tiwari, G., Dincer, I. and Reddy, BV V. 2009. Performace evaluation of a hybrid photovoltaic thermal (PV/T) (glass to glass) system. Int J Thermal Science; 48, pp. 154-64.

Ju, X., Xu, C., Han, X., Du, X., Wei, G. and Yang, Y. 2017. A review of the concentrated photovoltaic/ thermal (CPVT) hybrid solar systems based on the spectral beam splitting tech- nology. Appl Energy; 187, pp. 534-63.

King, D. L., Boyson, W. E., and Kratochvill, J. A. 2004. Photovoltaic array performance model. Online; 8: pp. 1-19.

Loveday, D. and Taki, AH. Convective heat transfer coefficients at a plane surface on a full-scale building facade. Int J Heat Mass Transfer 1996; 39, pp. 1729-42.

Mohd-Ghazali, N. 2014. Optimization of square and circular ammonia-cooled microchannel heat sink with genetic algorithm. Energy Procedia, 61, pp. 55-58.

Micheli, L., Fernández, F., Almonacid, F., Mallick, TK. and Smestad, GP. 2016. Performance, limits and economic perspectives for passive cooling of high concentrator photovoltaics. Solar Energy Mater Sol Cells; 153, pp. 164-78.

Radwan, A., Ahmed, M. and Ookawara, S., 2016. Performance enhancement of concentrated photovoltaic systems using a microchannel heat sink with nanofluids. Energy Conversion and Management, 119, pp. 289-303.

Radwan, A., Ookawara, S. and Ahmed, M., 2016. Analysis and simulation of concentrating photovoltaic systems with a microchannel heat sink. Solar Energy, 136, pp. 35-48.

Radwan, A. and Ahmed, M. 2017. The influence of microchannel heat sink configurations on the performance of low concentrator photovoltaic systems. Applied Energy, 206(May), pp. 594-611. 
Royne, A., Dey, C.J. and Mills, D.R., 2004. Cooling of photovoltaic cells under concentrated illumination: a critical review, Sol. Energy Mater. Sol. Cells. 86, pp. 451-483.

Patankar, S.V. 1980. Numerical Heat Transfer and Fluid Flow. Hemisphere, NY.

Sarhaddi, F., Farahat, S., Ajam, H., Behzadmehr, A., and Adeli, M. M. 2010. An improved thermal and electrical model for a solar photovoltaic thermal (PV / T) air collector. Applied Energy, 87(7), pp. 2328-2339.

Siddiqui, U., Arif, A. 2013. Electrical, thermal and structural performance of a cooled PV module: transient analysis using a multiphysics model. Applied Energy; 112, pp. 300-12.

Sun, Y., Wang, Y., Zhu, L., Yin, B., Xiang, H. and Huang, Q. 2014. Direct liquidimmersion cooling of concentrator silicon solar cells in a linear concentrating photovoltaic receiver, Energy. 65, pp. 264-271.

Tripanagnostopoulos Y., Nousia T., Souliotis M. and Yianoulis P. 2002. Hybrid photovoltaic/ thermal solar systems. Solar Energy; 72, pp.217-34.

Tuckerman, D. and Pease, R. 1981. High-performance heat sinking for VLSI, IEEE IEEE Electron Device Letters; pp. 126-129.

Wang, Y. 2017. Experimental study on direct-contact liquid film cooling simulated dense-array solar cells in high concentrating photovoltaic system. Energy Conversion and Management, 135, pp. 55-62.

Qu, W. and Mudawar I. 2002. Experimental and numerical study of pressure drop and heat transfer in a single-phase micro-channel heat sink, International Journal of Heat and Mass Transfer 45, pp. 2549-2565.

$\mathrm{Xu}$, S. 2016. Optimization of the thermal performance of multilayer silicon microchannel heat sinks., Thermal Science, 20(6), pp. 2001-2013.

$\mathrm{Xu}, \mathrm{Z}$. and Kleinstreuer, C. 2014. Concentration photovoltaic-thermal energy cogeneration system using nanofluids for cooling and heating. Energy Conversion and Management, 87, pp. 504-512.

Yang, K. and Zuo, C. 2015. A novel multi-layer manifold microchannel cooling system for concentrating photovoltaic cells. Energy Conversion and Management, 89, pp. 214-221.

Zhou, J., Yi, Q., Wang, Y., and Ye, Z. 2015. Temperature distribution of photovoltaic module based on finite element simulation. Solar Energy; 111, pp. 97103. 